\title{
Lugar e significado da gestão pombalina na economia colonial do Grão-Pará
}

Francisco de Assis Costa

Professor da UFPA

\begin{abstract}
Palauras-chave
Amazônia, História Colonial, Período Pombalino.
\end{abstract}

Classificação JEL N56, N96.

\author{
Key words \\ Amazon Region, Colonial \\ History, Pombal's Era.
}

JEL Classification N56, N96.

\section{Resumo}

A historiografia sobre o período colonial na Amazônia supõe uma realidade moldada pela oposição entre um projeto colonial agrícola e a ocorrência de situações concretas de economias extrativistas, a depender da disponbilidade de capital a ser aplicado no principal meio de produção, o escravo negro. De modo que um longo período de escassez de recursos teria conformado o ciclo da economia extrativista na Região dominado pelas "drogas do sertão", substituído por esforços da gestão pombalina por um ciclo agrícola. A gestão pombalina seria a inflexão para uma dinâmica estruturada pela agricultura que, alimentada adiante por conjunturas do mercado mundial, sobretudo as ligadas à guerra da independência americana, só encontraria limitação importante na emergência do novo ciclo extrativista centrado na borracha. Os resultados aqui discutidos não demonstram ser a período pombalino o momento em que, enfim, se estabeleceram os fundamentos da economia amazônica. Trata-se, na verdade, de fundamental e criativo momento de uma trajetória que, todavia, já iniciara quase $3 / 4$ de século antes, se impôs ao protagonismo reformador que marcou o período e dele recebeu condicionantes que marcaram indelevelmente a história da Região- até os dias atuais.

\section{Abstract}

The historiography on the colonial period in the Amazon involves an opposition between reality shaped by a colonial agricultural project and the occurrence of concrete situations of extractive economies, depending on the availability of capital to be applied in the main means of production: the black slave. So, a long period of scarcity of resources would have conformed a cycle of the extractive economy in the region dominated by the "drogas do sertão", replaced with an agricultural cycle as the very result of Pombal's management.

This period would be the turning point for a dynamics determined by agriculture, which improved on by world market situations, particularly those linked to the independence war in the USA, would find significant limitation only with the emergence of the new cycle centered on extractive rubber, which began around the second half of the XIX century. The results discussed here do not show that Pombal's period is the moment when finally the foundations of the Amazon economy were established.

In fact, it was a vital and creative time for a trajectory, which even though started almost $3 / 4$ of a century before, imposed itself marking the reforms of the period, which in turn conditioned indelibly the history of the region. 


\section{1_Introdução}

A historiografia brasileira, chamemos "clássica", sobre o período colonial na Amazônia ${ }^{1}$ supõe uma realidade moldada pela oposição entre um projeto colonial agrícola e a ocorrência de situações concretas de economias extrativistas, a depender da disponibilidade de capital a ser aplicado no principal meio de produção, o escravo negro. De modo que um longo período de escassez de recursos teria conformado o ciclo da economia extrativista na região dominado pelas "drogas do sertão", até o reinado de D. José I, substituído por um ciclo agrícola favorecido pela relativa abundância de capitais do período pombalino. A gestão pombalina seria $a$ inflexão, o turning point, que marcaria a passagem da situação insustentável representada pelo extrativismo, para uma dinâmica estruturada pela agricultura, que, alimentada adiante por conjunturas do mercado mundial, sobretudo as ligadas à guerra da independência americana, só encontraria limitação importante na emergência do novo ciclo extrativista centrado na borracha (Dias, 1970; Reis, 1944; Tocantins, 1960; Santos, 1980).

Com efeito, o movimento de ideias e o conjunto de providências da gestão pombalina na Amazônia (1750-1777), pelo vi- gor, intensidade e, não menos importante, presença documental, têm merecido qualificativos de "projeto de civilização para o Brasil" (Almeida, 1997), de "projeto de vassalização dos indios e extensão e identificação da colônia com o reino" (Domingues, 2000) e de "projeto de fomento [=desenvolvimento] pelo mercantilismo" (Dias, 1970). Em termos amplos, entende-se a gestão pombalina no quadro do problema maior da transição do feudalismo para o capitalismo, em que o governo do marquês de Pombal constitui

[...] Mercantilismo de tipo clássico, tardio mas ajustado à defasagem da sociedade lusa, adequado ao absolutismo reformador que dele se serve como instrumento de aceleração das mudanças (Falcon, 1982, p. 483).

Tal projeto teria a intenção, em última instância, fiscal e industrializante, com recuperação da capacidade de controle dos resultados do comércio na Metrópole e na América (Cardoso, 1990, p. 95).

$\mathrm{Na}$ Amazônia, as análises ressaltam como finalidade comum de todos esses projetos a negação da economia extrativista reinante: seja pela afirmação de uma agricultura de plantation baseada em escravos negros (Dias, 1970), seja pela afirmação de um campesinato agrícola (Almeida, 1997, p. 194-195; p. 277-280; Domingues, 2000, p. 73).

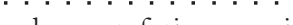

Quando nos referimos aqui

à Amazônia, temos em mente as informações e análises relativas ao componente do Grão-Pará na Colônia do Grão-Pará e do Maranhão. 
A análise de Cardoso (1984), não obstante consoante com as linhas gerais desse debate, vai além, indicando o período pombalino como marco de um movimento estrutural de passagem de um "sistema econômico" que prevaleceu por um século, entre 1650 e 1750, dominado pelas "drogas do sertão", mas com um setor agrícola subsidiário, e outro que se afirma a partir de 1750, com a política de Pombal, de cuja configuração fazia parte um setor dominante com um subsetor ascendente, constituído pela agricultura baseada em escravos negros e força de trabalho livre, e outro decadente baseado em coleta, dependente do sistema de repartição da força de trabalho indígena. Deste último faria parte um campesinato agrícola subsidiário,

\section{[...] heteróclito como no passado (peque- nos proprietários ou posseiros livres, bran- cos, mestiços on indios; $e$ as atividades autônomas consentidas aos escravos ne- gros nas fazendas), e que teve importante extensão (Cardoso, 1984, p. 197-198).}

Tomadas em conjunto, essa leitura do período pombalino permite as seguintes hipóteses: dado que o Diretório dos Índios, a nova institucionalidade estabelecida, seria um plano econômico de governo com o propósito último de estabelecer a agricultura na base produtiva da Colônia, o cresci- mento da economia do Grão-Pará deveria se fazer através do crescimento da sua componente agrícola e, como implicação necessária, a partir da transformação dos índios em "[...] um estrato camponês amerindio integrado na economia de mercado [...]" (Domingues, 2000), ou da implantação, enfim, de uma plantation escravista eficiente: em parte fruto da introdução de capitais exógenos materializados em escravos negros e outros instrumentos de trabalho carreados pela gestão pombalina (Dias, 1970), em parte produto da acumulação interna realizada no período anterior (Cardoso, 1984). Parte da ideia é que o desenvolvimento comercial que se espera da Companbia de Comércio do Grão-Pará e do Maranbão deverá estar a serviço desses propósitos e, como tal, ser percebido como base da melhoria do intercâmbio da Colônia com o resto do sistema (Dias, 1970; Shikida, 2007) em favor da Metrópole (Falcon, 1982; Cardoso, 1990).

O propósito deste artigo é testar esses enunciados de dois modos: na comparação com o passado e o futuro da Colônia, isto é, verificando a relação do período propriamente pombalino com as fases pré-e pós-reformas, e na observação, com o nível de detalhe permitido pelos dados disponíveis, das mudanças próprias ao período em que reinou D. José I. Como adiante se esclarecerá melhor, considerar-se-á o início 
do período "propriamente pombalino" não 1750, quando começa o governo e Mendonça Furtado é enviado ao Grão-Pará, mas $\operatorname{sim} 1755$, quando se estabelecem os grandes marcos institucionais do Diretório dos Índios e da Companhia do Comércio do Grão-Pará e Maranhão. O ano final, por seu turno, coincidirá com a liquidação desta última no ano 1777.

Para a comparação entre os subperíodos, haverá de se recorrer a séries históricas obtidas para o período de 1720 a 1822 , cujas fontes e metodologias de interpolação estão apresentadas no Anexo, na Tabela A-1. Com tais dados, verificaram-se as relações econômicas expressas adiante nas equações 1 a 8, para cada período. As equações mencionadas decompõem a expressão mais macro do sistema colonial, aquela que representa a totalidade dos rendimentos obtidos desde a exploração do aparato produtivo que lhe corresponde até sua realização no mercado mundial, em suas determinantes de rentabilidade e produtividade.

Se designarmos a produção física do Grão-Pará colonial como X'T, seu fundamento de recursos humanos (trabalho e gestão) por $\mathrm{P}$, a sua dimensão macro teria uma expressão em Y\$, tal que:

$$
\begin{aligned}
& \mathrm{Y} \$(\mathrm{Y} \$ \mathrm{X} \$) \cdot(\mathrm{X} \$ \mathrm{P}) \cdot \mathrm{P} \\
& (\mathrm{Y} \$ \mathrm{P})=(\mathrm{Y} \$ \mathrm{X} \$) \cdot(\mathrm{X} / \mathrm{P}) \\
& (\mathrm{X} / \mathrm{P})=(\mathrm{X} \$ / \mathrm{XT}) \cdot(\mathrm{XT} / \mathrm{P})
\end{aligned}
$$

onde Y\$ é o Valor Bruto da Produção da Colônia no Mercado Mundial (VBPM = X'T a preços vigentes do mercado mundial) e $\mathrm{X} \$$, o Valor da Produção Exportada na Colônia $(\mathrm{VBPC}=\mathrm{X} \mathrm{T}$ a preços de exportação de Belém para a Metrópole). A equação (1) diz que a expansão dessa economia, como parte de uma economia-mundo, depende da extensão do fator humano passível de incorporação pelo projeto colonial, $\mathrm{P}$, das condições internas que determinam a rentabilidade na aplicação desses recursos humanos na Colônia ( $\mathrm{x} \$=\mathrm{X} \$ / \mathrm{XT})$ e das condições externas à Colônia que determinam a capacidade de formação de valor adicionado a partir da Metrópole $(\mathrm{m}=\mathrm{Y} \$ / \mathrm{X} \$=\mathrm{XT} . \mathrm{y} \$ / \mathrm{XT} . \mathrm{x} \$=\mathrm{y} \$ / \mathrm{x} \$$, para $y \$$ e $x \$$ sendo, respectivamente, os preços no mercado mundial e os preços na Colônia).

Poder-se-ia em primeiro plano afirmar que a eficiência será correlata ao resultado da aplicação de cada unidade de recurso humano na Colônia $(y \$=Y \$ / P)$, como se lê na equação (2). Por fim, a equação (3) estabelece que as condições internas resultam da produtividade física $(\mathrm{xt}=\mathrm{XT} / \mathrm{P})$ e do preço da produção exportada da Colônia $(x \$=X \$ / X T)$.

Uma leitura dinâmica seria a de que a expansão do sistema

$\Delta \mathrm{Y} \$=\Delta \mathrm{m}+\Delta \mathrm{x} \$+\Delta \mathrm{P}$ 
será feita tanto mais rapidamente quanto maior o crescimento da sua produtividade monetária

$\Delta y \$=\Delta \mathrm{m}+\Delta \mathrm{x} \$$

que, por sua vez, depende das variações observadas nas condições externas e internas de operação de seus fundamentos transacionais e produtivos, respectivamente,
$\Delta \mathrm{m}=\Delta \mathrm{y} \$-\Delta \mathrm{x} \$$

$\Delta \mathrm{x} \$=\Delta \mathrm{xt}+\Delta \mathrm{x} \$$

As taxas $\Delta$ encontradas por regressão linear da transformação logarítmica de cada variável tomada individualmente, em relação ao tempo, constam da Tabela 1 e cumprem as condições das equações a diferenças (4) a (7).

Tabela 1_ Taxas de evolução das principais variáveis da economia colonial do Grão-Pará

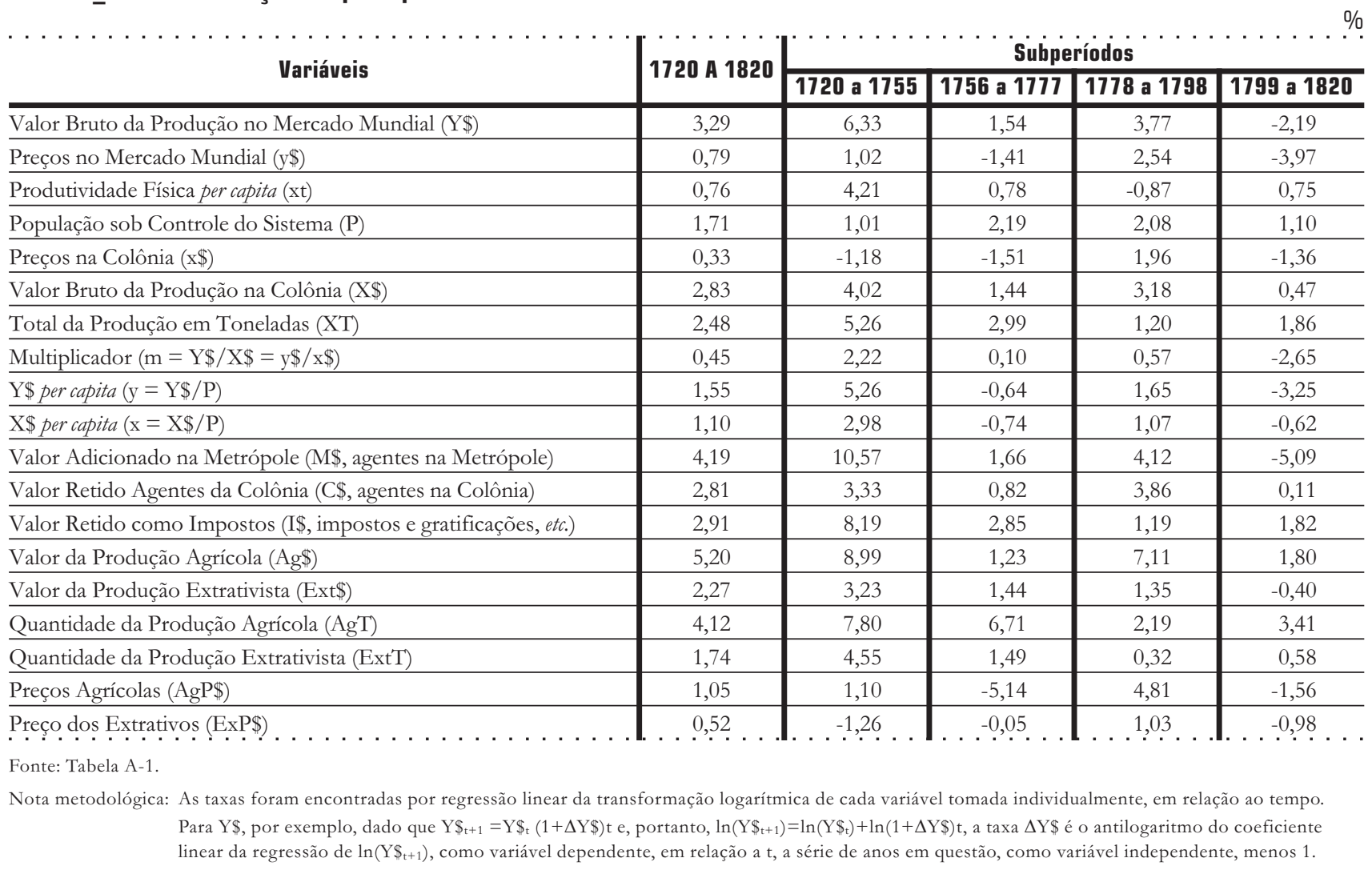


Tal dinâmica é avaliada de modos distintos por três diferentes grupos de protagonista: 1) Os agentes econômicos que, na Metrópole, gerem o processo de transformação, pelo comércio ou pela indústria, de XT em Y\$; 2) os agentes que, na Colônia, gerem os fundamentos da produção de XT, e 3) os agentes que garantem os rendimentos do Estado colonial.

Para os agentes na Metrópole, XT chega como um custo X\$ $=\mathrm{XT}$.x $\$$, definido por $\mathrm{x} \$$ - preço pago na Colônia aos agentes lá assentados - e lhes escapa como uma receita $\mathrm{Y} \$=\mathrm{XT} . \mathrm{y} \$$, definida por $\mathrm{y} \$-$ preço pago no mercado mundial pelos produtos da Colônia. Esses agentes observam o mundo pela relação m já acima discutida, a relação que representa a formação de valor adicionado (m), na Metrópole, onde se inclui lucro mercantil, processamento industrial, receitas de serviços, como transporte, salários e rendimentos diversos. Expressando em y $\$$ grau de monopólio da Metrópole no mercado mundial e em $\times \$$ o grau de monopsônio na Colônia, $\mathrm{m}(=\mathrm{Y} \$ / \mathrm{X} \$=\mathrm{y} \$ \mathrm{XT} / \mathrm{x} \$ . \mathrm{XT}=$ $y \$(x \$)$ indica, por outra parte, a massa de valor, cujo acesso justifica o empreendimento colonial à luz de seus gestores.

Importa, afinal, aos agentes do primeiro tipo sua participação no valor dado por $\mathrm{M} \$=\mathrm{Y} \$-\mathrm{X} \$$. Os agentes do Estado imputam tributos i sobre XT em montante i $\$ . X T=I \$$ aos agentes privados na Colônia ${ }^{2}$ associados à obtenção dos produtos para exportação. Estes últimos se compõem com os agentes que lhes fornecem insumos intermediários para ensacamento e outras necessidades na apropriação de $\mathrm{C} \$=X \$-I \$$, de modo que o resultado do empreendimento colonial se comparte nas parcelas:

$\mathrm{Y} \$=\mathrm{M} \$+\mathrm{C} \$+\mathrm{I} \$$

distribuídas, respectivamente, pelos agentes na Metrópole, agentes na Colônia ligados à produção para exportação e pelos agentes do Estado. Tal partição apresenta um potencial de conflito, de um lado em torno de $\mathrm{x} \$$ entre os agentes que acessam $\mathrm{C} \$$ com os que acessam $\mathrm{M} \$$; de outro, sobretudo em torno de i, entre os primeiros e os agentes que acessam I\$. As taxas $\Delta$ que se encontram na Tabela 1 , de variação das parcelas de (8), expressam o nível desse potencial e, ponderadas pela respectiva participação relativa, somam $\Delta Y \$$. De maneira que, quando a taxa de variação de uma parcela é maior que a taxa de variação do total, sua participação relativa cresce, e, quando menor, diminui no período tratado.

A estrutura do trabalho, que tem três seções além desta introdução, seguirá a periodização já indicada: na seção 2 , serão discutidos os períodos pré-pombalinos - O 2 Alden (1974) apresenta no Apêndice III as fórmulas de cálculo de impostos sobre cacau e sobre outras "drogas do sertão", como o cravo. Para o cacau, 410 réis/arroba; para o cravo, 620 réis/arroba. Custos de embalagem do cacau, 100 réis/arroba; para o cravo, 200 réis/cesto. 
período das missões e preações na subseção 2.1, e o período dos aldeamentos na subseção 2.2; na seção 3, o período da gestão pombalina; na seção 4, os períodos pós-Pombal - o que vai até o fechamento dos Diretórios na subseção 3.1 e o que vai desse momento até o fim do período colonial, 1822. Posteriormente, serão apresentadas as conclusões.

\section{A Colônia do Grão-Pará no período Pré-Pombalino (1616-1755)}

Há dois subperíodos a tratar antes da gestão do marquês de Pombal. O primeiro, marcado pela oposição missão X preação, estende-se da fundação da Colônia, em 1616, até 1686, quando se estabelece o Regulamento das Missões. Trata-se de fase para a qual não se dispõe de séries históricas de nenhuma das variáveis econômicas relevantes, de modo que sobre ela nossas observações serão com base unicamente na bibliografia disponível. O segundo subperíodo, marcado pela dominância dos aldeamentos à sombra da gestão das ordens religiosas sob o Regulamento das Missões, vai de 1687 até o início das reformas pombalinas, em 1755. Para esse período, conseguimos organizar séries de variáveis relevantes de 1720 em diante, as quais, em adição às fontes bibliográficas, subsidiarão nossas observações.

\section{1_Missão e preação - 1616 a 1686}

Quando os portugueses chegaram à Amazônia, em 1616, buscavam tornar a região uma extensão da economia colonial de plantation, cujos pilares eram a mão de obra escrava africana e a produção especializada de mercadorias coloniais. O Império Colonial português havia acumulado reconhecida experiência nesse modelo, especialmente na produção do açúcar, primeiro, ainda no século XV, nas suas ilhas do Atlântico, em especial nas Ilhas Madeira, e depois, no século seguinte, no Nordeste brasileiro (Furtado, 1976, p. 5-18), e pretendia estendê-lo até aqui. $\mathrm{O}$ específico das condições naturais que encontraram na Amazônia, entretanto, extrapolou os limites das técnicas agronômicas já dominadas.

Com efeito, as pretensões de produzir os produtos já consagrados no mercado sucumbem ante os experimentos iniciais que demonstraram a baixa produtividade da região para a agricultura do tipo praticada em outros pontos do Império - em monoculturas de grandes extensões. Relatos desse reconhecimento pontuam todo o período colonial (Tocantins, 1960, p. 60-65; Prado Jr., 1987, p. 69; Sodré, 1987, p. 129). Todavia, a dificuldade não inviabilizou a Colônia do Grão-Pará, porque o es- 
pecífico do ecossistema amazônico mostrou sua outra face: a condição de produzir, nos seus processos originais, bens capazes de se tornarem mercadorias para o mercado mundial. A natureza originária da região, em sua singularidade e estranheza, ao tempo que limitou as possibilidades de obtenção de mercadorias agrícolas capazes de garantir lucro mercantil, regalou o colonizador com produtos "prontos", carecendo apenas de ser recolhidos. Logo se constatou que muitos desses produtos seriam equivalentes ou substitutos de especiarias para as quais já havia mercado consolidado na Europa, cujas rotas de comércio procedentes do Oriente encontravam-se vedadas a Portugal (Costa, 1989).

Não obstante, tratava-se de uma oportunidade cujo aproveitamento forçaria uma revisão dos termos do projeto colonial amazônico. Nesse difícil processo, pelo qual experiências passadas viriam a fracassar, se mostrando insuficientes, perspectivas teóricas se confrontaram, e experimentos se tornaram necessários. De modo que processos adaptativos concorrentes que produziram, ao final, novas possibilidades de exploração da Colônia em bases extrativistas marcaram o primeiro século da colonização da região (Costa, 1989).

A passagem de um projeto agrícola de um ideal de civilização de base agrícola
- para uma prática sistemática e dominante do extrativismo de coleta trouxe duas ordens de problemas:

i. Problemas decorrentes da redefinição do papel da agricultura, da condição de base de exportação para a de supridora de necessidades internas à Colônia. Resultam, daí, fortes restrições estruturais para a obtenção de meios de produção no mercado mundial, em particular do escravo negro - mercadoria cara, cuja obtenção requeria necessariamente meios de pagamento internacionais.

ii. Problemas decorrentes da redefinição do trabalho índio no contexto de uma economia baseada no extrativismo de coleta. É necessário, para encaminhar este ponto, que se distinga "extrativismo de coleta" de "extrativismo de aniquilamento". No "extrativismo de aniquilamento", o trabalho do extrator "anula" as propriedades originais do ecossistema, tomando suas partes, seus componentes estruturais como estoque de matérias independentes e genéricas (a madeira, a raiz, etc.). Nesse caso, o ecossistema tornou-se objeto (do 
$\cdots \cdots \cdots \ldots$

3 O custo de um índio era, em 1693, de $6 \$ 000$ por peça, sendo a metade de tributo a El-Rey. Em 1682, o preço do escravo negro vendido no Grão-Pará e no Maranhão era de $100 \$ 000$ por cabeça. Em 1732, um índio escravo custava na praça do Pará 5\$000. A média de preços dos escravos negros de diversas origens e desembarcados em Belém, de 1757 a 1777, pela Companhia do Grão-Pará e do Maranhão foi de $68 \$ 441$

(Conf. Azevedo, 1999, p. 151 e seguintes; Dias, 1970, p. 466). poder transformador) do trabalho do extrator. $\mathrm{O}$ "extrativismo de coleta", ao contrário, supõe a preservação da natureza originária, dado que é a produtora, no exercício de suas funções reprodutivas, dos valores-de-uso, que, como um fluxo, são colhidos por ação imediata do trabalho do extrator. Consequentemente, no "extrativismo de coleta", a efetividade do trabalho depende do conhecimento que se tenha dos fundamentos da produção dos bens em questão i.e. do conhecimento que garanta domínio (cognitivo) do processo produtivo da natureza originária. Tal conhecimento é fundamental para que se repitam os movimentos que fazem fluir, como processo social, dos mesmos pontos no espaço, e no tempo próprio da natureza, a torrente - tanto mais caudalosa, tanto melhor - de produtos que afirmarão, no tempo do capital, o sistema mercantil. Aos agentes mercantis cabe a ação mediata de transformar sistematicamente essa produção contínua da natureza - que, nesse sentido, se torna um capital em sua forma original - em mercadorias.
Relacionadas, as questões derivadas da redefinição do papel da agricultura e as provindas da redefinição do trabalho indígena configuraram os dilemas da colonização amazônica - sua especificidade comparativamente a outras experiências.

As primeiras não são exclusivas da Amazônia. Como se reconhece amplamente, elas estão presentes nas outras colônias com função de suprimento interno, como as de São Vicente e da Região das Missões (Maranhão, 2006). Como naquelas, também aqui a agricultura de baixa rentabilidade (em divisas, meios de circulação na economia-mundo) colocava a força de trabalho indígena como uma alternativa mais barata ${ }^{3}$ perante a do negro africano. Sua utilização, contudo, sempre vista pelos historiadores como uma segunda opção (second best choice), uma alternativa reconhecidamente inferior.

Diferentemente daquelas, entretanto, as questões afetas à requalificação do extrativismo de coleta, sua centralidade no projeto colonial na Amazônia, constituem condição específica, posto que praticamente excluíam a utilização eficiente de um trabalhador não conhecedor do meio ambiente amazônico e, assim, requalificavam no projeto colonial tanto o europeu ou o africano - agora incapazes - quanto o indígena, único capaz. 
De modo que a questão do acesso ao trabalho indígena, que nas outras colônias se associava às condições de determinação do custo de produção e da rentabilidade da produção colonial, tanto mais rentável esta, tanto menos importante aquela, aqui se torna o pressuposto da existência, ou não, dessa produção e, assim, condição sem a qual o projeto colonial, como empreendimento mercantil, seria posto em dúvida.

Dar conta dessa realidade, vivenciála como cristão ou pagão e operá-la, como padre, mercador ou militar, não terá sido tarefa simples, nem pacífica. Para os agentes coloniais, faltava visão de mundo que acomodasse a consciência nessa nova situação. Mostravam-se inadequadas as estruturas ideológicas dominantes para as novas práticas estruturais. Derivaram daí contradições graves, que emergiram, primeiro, na forma de um grande confronto entre religiosos e leigos - entre missões e preações. Depois, os antagonismos forjaram soluções - configuram novos arranjos que garantiram os ajustamentos necessários à continuidade do projeto.

Para se avançar nesta matéria, um parêntese para uma digressão teórica. É nossa compreensão que a situação amazônica não se ajusta à frequente esquematização, que, no trato da história do Império Colonial português, ou colocam as institui- ções religiosas a serviço incondicional da colonização como empreendimento econômico, sua "ponta de lança", ou absolutizam os antagonismos entre as práticas religiosas nas colônias e os objetivos coloniais da Coroa portuguesa e a política das ordens na Metrópole. Observamos, por isso, as ordens religiosas por um prisma que, se de um lado não as coloca nem contra, nem alheias à colonização, de outro favorece à expectativa de que suas relações com projeto mercantil alteram-se de situação para situação. Como indica Baeta Neves,

\section{[...] variam [...] suas formas de aproxi- mação, aliança, afastamento ou ruptura com setores sociais determinados na colô- nia e/ ou com certas politicas governamen- tais de colonização (Neves, 1987, p. 106).}

No Império como um todo, uma aliança se cristalizou no amparo políticomilitar recebido dos Governos Gerais para que a política de catequese indígena tivesse sido viável. Em contrapartida, as ordens religiosas deram apoio ideológico à obra de colonização. Não obstante, há dissenso, desde os primórdios da ocupação efetiva, entre, por exemplo, a política jesuítica relativa ao indígena e a desejada por setores significativos da população (Neves, 1987).

Nesse quadro, um serviço inestimável das instituições religiosas ao colonialismo 
foi o de produzir a equivalência ideológica entre empreendimento colonial e civilização e, desta, com a cristianização. Por transitividade, produziu-se uma nova equivalência que, em última instância, divinizava o colonialismo.

Importante aduzir, porém - pois se trata de aspecto central no caso da Amazônia - que essas equivalências não se fazem de forma direta. Elas são mediadas por diversas outras noções necessárias, entre as quais a de que o colonialismo é portador da civilização porque atua na transformação da natureza bruta - os ecossistemas originários, as florestas, os matos, os sertões vista como espaço vazio, passível da ocupação pelo mal, lugar da desordem, não tocado por Deus, a não ser no momento da criação, domínio do diabo... O colonialismo provê a ocupação desse lugar obscuro, pela agricultura, tornando-o um lugar - aberto, claro, controlado, civilizado - pleno de novos homens ganhos para a verdade de Deus, primeiro pelo trabalho e pela disciplina.

É razoável assumir, isso posto, que as ordens religiosas dão suporte teológico às polaridades ideológicas do projeto colonial, as quais opõem natureza bruta (e homens sem alma a ela associados) à natureza transformada (e os homens cristianizados que a transformam) do mesmo modo que opõem a barbárie à civilização.
Contudo, divergências se sucedem em muitos momentos da ocupação, entre a política jesuítica relativa ao indígena e a desejada por setores significativos da população. No caso da Amazônia, a necessidade de justificar o extrativismo de coleta (i.e., não "transformador") como obra civilizatória trouxe formas dramáticas de tensão - e, muito importante, inovadores trajetos de solução.

Qual a moral que acomoda compulsão de força de trabalho com o propósito de atuar com, não contra, a natureza bruta, originária? Que formas de compulsar a única força de trabalho capaz de dar conta dos processos necessários à transformação das dádivas da natureza bruta em mercadoria, o índio?

A segunda metade do século XVII foi consumida, no Grão-Pará, em confrontos, teóricos e práticos, em torno dessas questões. Dois caminhos apresentaram-se, num primeiro momento, de forma excludente, em seguida, conformando uma unidade histórica - uma institucionalidade fundamental, o padrão regulatório que garantiu a gênese da economia colonial amazônica.

Duas formas de compulsão da força de trabalho indígena, pois, foram colocadas em prática: uma militar, outra cultural. A primeira representada pela proposta dos colonos leigos da escravização pura e 
simples do gentio, dos seres sem Deus; a segunda, oriunda do fervor missionário das ordens religiosas, apresentava uma pedagogia deculturadora, uma metodologia de transformação sem dor dos "inocentes" (pois ainda não tocados pela verdade), "pagãos" ofensivamente livres, em homens disciplinados para o louvor a Deus e para os trabalhos da terra, das águas, dos matos.

A metodologia escravista sucumbe ante dois fatos. O primeiro consistiu na verificação de que a atividade extrativa, por se exercer em áreas tão amplas e de conformação tão complexa, dificulta enormemente o controle do trabalhador, sem o que a relação escravista torna-se impossível. A segunda associa-se à verificação da imensa depredação causada nas fontes de força de trabalho pelos instrumentos militares do escravismo. Cálculos de Orlando Costa demonstram que, de 1655 a 1660, em seis anos, portanto, para escravizar 6.700 índios, foram empreendidas "guerras justas", "resgates" e "preações" que levaram à morte várias centenas de milhares de índios (Costa, 1969, p. 60).

A violência dos colonos "tange" os índios para as aldeias, criando a força de trabalho da qual se lança mão nas expedições de coleta de "drogas do sertão" - fonte principal das rendas mercantis - e na construção de um aparelho de Estado e de equipamentos religiosos (Pe. João Daniel, v. 1, p. 311-315, 2004).

Montava-se, assim, um curioso mecanismo de formação da força de trabalho que, in limine, resultava sob controle do conjunto dos agentes coloniais. As pendengas e querelas entre colonos e padres que emergem em profusão dos documentos da época desviam a atenção deste fato: aparentemente uns contra os outros, ou, melhor formulado, uns contra os outros nos dissensos ideológicos do projeto colonial em lugar e tempo particulares que os interpelavam com novos desafios, os agentes religiosos e leigos, por razões santas, privadas ou da Coroa, agiram de modo que se mostraram complementar, resultando em estruturas operacionalmente convenientes à revisão dos termos do projeto de colonização da região. Com efeito, as iniciativas privadas dos colonos na obtenção de escravos índios, corroboradas por uma legislação ambígua e por práticas governamentais locais estruturalmente tolerantes, recolocavam continuamente a possibilidade do cativeiro diante das populações indígenas, que, dispondo da alternativa dos aldeamentos, se submetiam ao controle religioso das missões. Estas, inicialmente, reafirmando seu papel ciosamente defendido em outros lugares, de proteção dos índios, sonegaram a força de trabalho sob seu 
controle. E, precisamente, esse é o ponto nefrálgico das contendas.

Dois institutos normativos estabeleceram os marcos desta matéria, no conjunto resguardando sua lógica fundadora: o Regimento das Missões de dezembro de 1686 e o Alvará de 28 de abril de 1688 . O primeiro instituto, formulado com base nas doutrinas de Antônio Vieira e na experiência missionária acumulada ao longo do século XVII no contexto da disputa com os colonos, assentou as regras para a administração dos índios. A par de assegurar a liberdade dos aldeamentos aos indígenas e de garantir a gestão desses estabelecimentos com o poder temporal e espiritual que continham - às ordens religiosas, o Regimento das Missões concedia aos demais agentes da Colônia o acesso à força de trabalho aldeada, tal que $1 / 3$ das disponibilidades fosse concedido aos colonos com licença promulgada pela administração colonial, 1/3 para as necessidades da Coroa e da administração colonial e 1/3 para uso dos próprios aldeamentos e das missões religiosas. O Alvará mencionado regulamenta exceções ao quadro geral do Regimento, quando autoriza a escravidão de índios prisioneiros de guerra, condenados ao canibalismo ou rebelados por questões religiosas e políticas (Almeida, 1997, p. 156-162).

$\mathrm{O}$ produto da aplicação da força de trabalho pelos colonos seria objeto de tri- butação do Estado, ainda em sua forma física, após o que seu proprietário teria total direito de alienação, podendo decidir livremente sobre as fases subsequentes de transporte (para) e transação no reino (Alden, 1974 - Apêndice III).

Cria-se, assim, na colônia amazônica, uma totalidade contraditória particular, um modo de produção, com relações técnicas e sociais próprias, as primeiras caracterizadas pela dominância do extrativismo de coleta; as últimas fundadas na compulsão do trabalho índio, internalizado ao sistema por mecanismos de constrangimento de seu sujeito. O sucesso dos aldeamentos e das missões em congregar cada vez mais gente é a outra face da violência dos colonos escravistas. E, na salvaguarda da ordem colonial como um todo, os indígenas aldeados representavam a fonte de trabalho eficaz, no contexto dado, para o conjunto das atividades da Igreja, do Estado e dos colonos. Tal modo de produção fundou, de fato, a economia colonial amazônica, que se reproduziu por gerações, aguçando, contudo, no desenvolvimento, suas profundas contradições.

\subsection{O domínio dos aldeamentos missionários - 1720 a 1755}

O modo de produção regulado pelo Regimento das Missões e pelo Alvará de 28 de 
abril de 1688, combinado com a emergência de um novo produto colonial que se pôde encontrar aqui como "droga do sertão", o cacau, liberou as forças que garantiram um ciclo importante de desenvolvimento. Sua base institucional prevaleceu até 1755 - quando se estabeleceram novas formas de regulação advindas da gestão pombalina.

Para a série de 35 anos contínuos desse período dominado pelas missões, entre 1720 e 1755, a taxa média anual de crescimento da economia colonial amazônica representada por seu produto $\mathrm{Y} \$$ foi de $6,33 \%$ a.a., dos quais apenas $1,02 \%$ se explica na variação das condições externas à Colônia expressas nos preços implícitos y\$. Supondo um crescimento lento, de 1\% a.a., da população sob controle do sistema colonial, dadas as dificuldades, mesmo, de assimilação de indígenas, já mencionadas, e os surtos de epidemias importantes, como a de varíola nos anos quarenta (conf. Alden, 1974, p. 32), a forte expansão se deve, sobretudo, à propulsão de um crescimento da produtividade por unidade populacional do sistema, à taxa de 4,21\% a.a. Por seu turno, o crescimento subjacente da produção em toneladas - i.e. da expansão da capacidade efetiva do aparato de produção se fez ao ritmo acelerado de 5,26\% a.a., a um preço interno que declinou a $-1,18 \%$ a.a. (Tabela 1).
Nesse ponto, cabe distinção entre três fases do período. A fase inicial corresponde a um movimento fortemente crescente dos preços de 1720 até 1735 , com a quantidade exportada reagindo correspondentemente somente na segunda metade dos anos vinte. Quantidade e preço nesse período apresentam uma Correlação de Pearson positiva e mediana, de 0,6996 , e a primeira variável apresenta elasticidade superior a 1 em relação à segunda $(\Delta \mathrm{XT} / \Delta \mathrm{x} \$=13,3 \% / 8,5 \%=1,56)$. Isto é, para cada 1 ponto percentual de variação no preço, a quantidade cresce 1,56 pontos percentuais. A partir daí, tem-se uma nova fase, na qual os preços internos iniciam um processo de redução contínua, não correspondida diretamente pela quantidade exportada, que, ao contrário, mantém tendência de crescimento baseado em incremento da produtividade, até 1750. A Correlação de Pearson é agora negativa $(-0,7733)$, assim como a elasticidade da quantidade (crescimento a 2,5\% a.a.) em relação ao preço (a $-6,6 \%$ a.a.): $-0,38$. Por fim, nos últimos cinco anos, a quantidade cai rapidamente $(-6,5 \%$ a.a.) para os preços indicando ligeira recuperação $(1,6 \%)$.

Visto o conjunto dos movimentos, tem-se que a rigidez inicial da produção deu lugar a uma desenvolta expansão da quantidade exportada. Inicialmente, o crescimento seguiu indicação direta dos preços, 
os quais induziram a expansão da produção por incrementos sistemáticos na produtividade - derivados do aprendizado para aproveitamento das possibilidades do Regimento das Missões. Por essa via, os agentes da Colônia fizeram valer as oportunidades oferecidas por níveis de remuneração e preço jamais atingidos. Posteriormente, esses agentes, usando e aprimorando os fundamentos produtivos que construíram na primeira fase, sem precedentes na Colônia, fazem crescer a quantidade exportada, compensando, assim, na receita, a redução nos preços. O resultado final é um crescimento da produção física mais que proporcional ao crescimento da receita. E, dado que a tributação é feita sobre a base física, um crescimento também mais que proporcional das receitas do Estado (I\$).

Ademais, os preços internos à Colônia se movimentam, nessa fase, de acordo com o movimento dos preços no mercado mundial, porém em ritmos distintos: quando crescem, os preços internos crescem mais rapidamente que os externos, levando a uma queda na taxa de formação de valor adicionado na Metrópole $(\mathrm{M} \$$ ) e uma redistribuição dos resultados totais em favor dos agentes internos à Colônia (C\$); quando caem, os preços internos o fazem mais rapidamente que os externos, provocando movimentos inversos, agora em favor da formação de valor adicionado na Metrópole e os agentes que o compartem. As diferenças se expressam nas taxas de crescimento do período como um todo, a do valor adicionado na Metrópole, 10,57\% a.a., a do valor retido como impostos, 8,19\% a.a., e a do valor retido pelos agentes da Colônia, 3,33\% a.a., levando a que, no final, se verifique uma inversão das posições relativas - a participação dos agentes internos à Colônia, que era de $70 \%$ do valor gerado pelo empreendimento no início do período, passa a ser algo em torno de $30 \%$ no final; a participação dos agentes na Metrópole, por sua vez, saiu de $25 \%$ para se situar em torno de $55 \%$, e o Estado melhora sua posição para algo próximo de $15 \%$, quando fora $10 \%$ no início.

\section{A Colônia do Grão-Pará no período das Reformas Pombalinas (1755-1717)}

O marquês de Pombal enviou, em 1750, ninguém menos que seu irmão Francisco Xavier de Mendonça Furtado para governar a colônia amazônica, a qual, após um período de rapidíssimo crescimento, apresentara, nos últimos cinco anos, uma fase de lento andamento e produtividade constante. Nos primeiros cinco anos da gestão de Mendonça Furtado, com os 
preços em recuperação na Europa, cresce a rentabilidade - externa e interna, a primeira mais rápido que a segunda, criando um lag favorável à posição dos atores na Metrópole. A produtividade física, entretanto, entra em declínio, arrastando a produção que, em 1755, atinge o nível mais baixo desde 1730 .

Mendonça Furtado tomou contato com a crise naquilo que lhe dizia respeito mais de imediato: as finanças públicas, afetadas pela redução da base fiscal que era, como já mencionado, a quantidade produzida (Gráfico 1). Na indigência dos cofres públicos, o gestor via limites sérios à execução da política de segurança que lhe competia na missão de elevar os níveis de garantia da conquista. A tarefa exigia, a um só tempo, estabelecer com clareza os limites territoriais da Colônia, elevar sua fortificação militar e adensar seu povoamento. Sobre a economia, fundamento de tudo o mais, apresentou um diagnóstico em que a situação presente é dramaticamente relatada:

\section{Gráfico 1_ Evolução da participação relativa dos diversos conjuntos de agentes fundamentais na economia colonial 1720 a 1820 \\ (\% de Y\$, médias móveis quinquenais)}
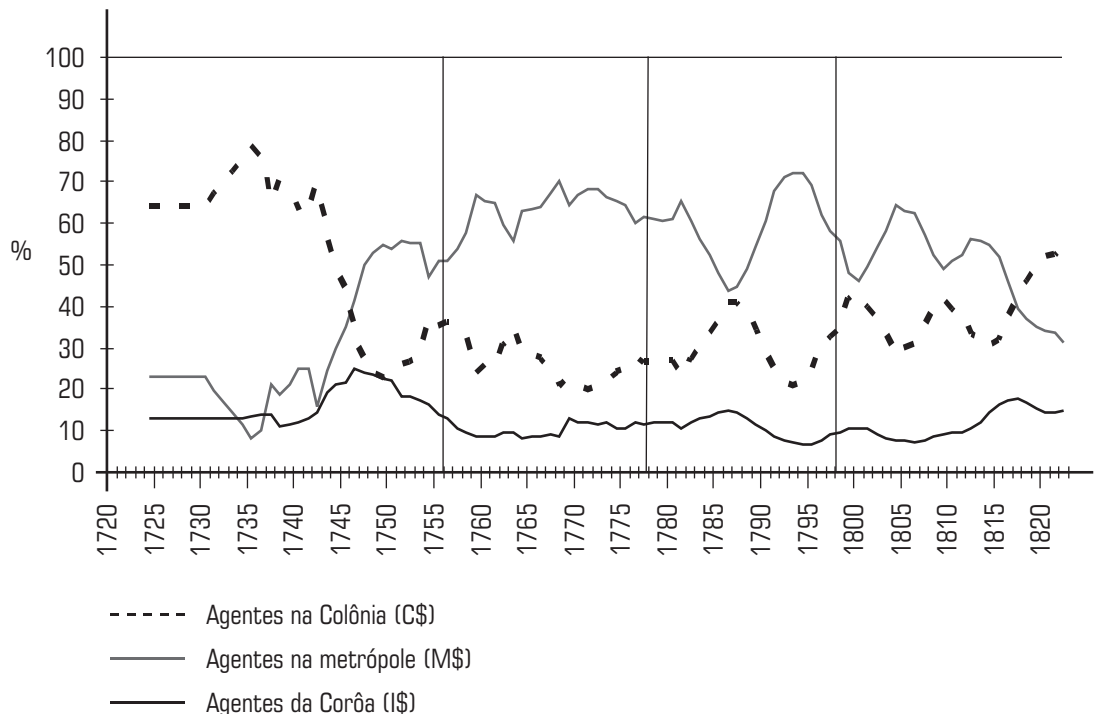

Fonte: Tabela A-1. 
[...] Este Estado, e principalmente esta Capitania, se acha reduzido à infima miséria; todos os seus moradores estão na última consternação. São poucos os que ainda cultivam alguns gêneros; a maior parte conserva algum indio escravo para ir buscar ao rio ou ao mato o miserável sustento cotidiano com o que passam pobrissimamente metidos em uma choupana a que eles chamam de rocas (Mendonça Furtado apud Mendonça, 1963, TI, p. 145).

Situação atual tanto mais consternadora, quando compara a um passado promissor:

[...] Ultimamente, mano, é necessário assentar em dois princípios certos, claros e evidentes. O primeiro, que este Estado se fundou, floresceu e nele se estabeleceram infinitos engenhos e plantações [...]. Depois [...] tudo se arruinou, confundiu e finalmente se reduziu a nada (Mendonça Furtado, apud Mendonça, 1963, TI, p. 84).

Em conjunto, a avaliação de que uma "florescente" agricultura teria sumido, dando lugar ao "nada" - ou ao caos da economia extrativa -, parecia ser explicação suficiente para a crise. Eram três os pontos centrais do "sistema", que, para Mendonça Furtado, teriam ensejado mudança tão drástica e estariam subjacentes aos problemas da Colônia: o controle da força de trabalho indígena pelos religiosos; a perversão dos religiosos pela riqueza associada ao extrativismo e a autonomia das ordens religiosas perante o Estado.

O controle da força de trabalho índio pelos religiosos teria levado a dois males: legara aos padres a possibilidade de se tornarem senhores dos matos, das "drogas do sertão", colocando-os diante de uma tentação que os impedia de cumprir suas verdadeiras funções, entre as quais se destacaria a de preparar mão de obra para a agricultura. Veja-se, por exemplo, o que contém a citação seguinte:

[...] a maior parte dos indios, sem outra doutrina ou cultura mais do que a de saberem tratar mal das fazendas, aprenderem alguns ofícios para utilizarem as religiões, e serem insignes em extrair drogas do sertão, que é o que são com todas as forças obrigados (Mendonça Furtado apud Mendonça, 1963, TI, p. 78, grifo nosso).

Esse ponto é importante nas considerações de Mendonça Furtado, já que é a base para a organização de outra noção que configura o segundo dos grandes males do controle da força de trabalho indígena pelos religiosos: a de que a agricultura não se desenvolvera (ou tivera seu desenvolvimento bloqueado) porque baseada na força de trabalho indígena, pouco produtiva, pois mal treinada, livre e indisciplinada. Os problemas da agricultura residiriam, as- 
sim, na inadequação (reforçada pela displicência das ordens) da força de trabalho.

[...] Toda esta gente é ignorante em infimo grau, imagina que toda sua fortuna lhe há de vir dos sertões [...] aprisionando indios, com os quais se propõem fazer grandes progressos em suas fábricas e lavoura. [...] Nas conversaçoes [...] thes vou dizendo [...] que os negros são melhores trabalhadores que os indios, e que eu espero vê-los por este modo remidos (Mendonça Furtado, apud Mendonça, 1963, TI, p. 260).

A perversão dos religiosos pela riqueza associada ao extrativismo os legava, assim, dupla condição, ambas negativas aos olhos de Mendonça Furtado. Tornavamnos opositores do desenvolvimento agrícola e opositores dos colonos, vassalos de Sua Majestade que, bem ou mal, significavam a real presença de domínio nesses ermos. Nesse ponto, Mendonça Furtado é severo.

[...] Não há circunstância alguma que deixe de capacitar-me que este poder que se deu aos regulares sobre os indios foi a rede mais sutil que podia inventar o Demônio, não sópara assolar os povos, mas para perder as almas, e converter em lôbos aqueles homens que os nossos Augustissimos Monarcas, com o zêlo cristianíssimo, deputaram para os padres, os quais prevaricaram inteiramente, depois que gastaram o tempo que deveriam empregar em conver- ter almas, em cuidar o modo que deveriam ajuntar tesouros, cujo vício leva atrás de sí todos os outros que se lhe peguem por natural consequencia [...] (Mendonça Furtado, apud Mendonça, 1963, TI, p. 260).

Em resumo, a autonomia das ordens religiosas perante o Estado e as demais instituições coloniais na Amazônia teria estabelecido o "fato" de que os religiosos dominavam o principal da economia regional. $\mathrm{O}$ fato de serem dispensados de pagar impostos, limitava a capacidade do Estado

$\begin{array}{ll}4 \text { A condenação das } & \text { favorecimento no uso desse } \\ \text { atividades econômicas dos } & \text { fator, naturalmente utilizada } \\ \text { missionários não foi original } & \text { no atendimento das } \\ \text { em Francisco Xavier e } & \text { necessidades das missões } \\ \text { Mendonça. Havia um século, } & \text { como sistema, como estrutura } \\ \text { as acusações de que os } & \text { material. Esse uso, entretanto, } \\ \text { religiosos dominavam a } & \text { poderia ter formas muito } \\ \text { economia colonial } & \text { diversas - e igualmente } \\ \text { repetiam-se. Segundo Alden, } & \text { importante - do emprego na } \\ \text { por duas vezes a Coroa } & \text { coleta das "drogas do sertão". } \\ \text { mandou investigar tais } & \text { Os aldeamentos poderiam } \\ \text { acusações, sempre com } & \text { muito bem estar negando } \\ \text { resultados negativos: os } & \text { trabalhadores às expedições de } \\ \text { religiosos tinham, sim, uma } & \text { coleta para aplicá-los na } \\ \text { produção, nunca sequer } & \text { construção de seminários ou } \\ \text { próximo do que se cogitava } & \text { em atividades quaisquer que } \\ \text { (Alden, 1974, p. 33-36). A } & \text { permitissem o } \\ \text { nossa opinião a respeito é de } & \text { desenvolvimento do conjunto } \\ \text { que a posição dos religiosos } & \text { dos aldeamentos. Enfim, um } \\ \text { era extremamente privilegiada } & \text { estudo ainda está por ser feito } \\ \text { em relação a um suposto vital } & \text { que permita dar conta } \\ \text { da economia regional. Isso } & \text { dessas questões. } \\ \end{array}$


em adquirir meios essenciais aos seus fins. Além disso, sendo o sistema dos aldeamentos praticamente autárquico, com divisão do trabalho interna e canais próprios de comercialização na Corte, as "religiões" recolhiam

[...] nas comunidades todo comércio que deveria girar na Praça, e com que deveram enriquecer-se aqueles homens, que nele traficam com tanto lucro do público e da fazenda real (Mendonça Furtado, apud Mendonça, 1963, TI, p. 145).

A solução para desarticular o "sistema presente", o qual

[...] enquanto se conservar, por mais tesouros que S. Maj. despenda, não será possivel nunca que floresça este estado, porque, como os regulares são senhores do comércio e dos povos, quanto mais dinheiro vier, tanto mais engrossarão os cofres das religiões, que hão de ser sempre senhores dos cabedais que giram (Mendonça Furtado, apud Mendonça, 1963, TI, p. 145)

foi sugerida já em carta de 18 de janeiro de 1753. Ali se propunham dois conjuntos associados de medidas econômicas e políticas. As medidas econômicas se enfeixavam no propósito de restabelecer o modelo agrícola colonial, fundado no trabalho escravo negro. Aqui desempenharia papel fundamental uma "companhia de comércio" que monopolizasse as relações mercantis da Colônia - transportando e vendendo seus produtos (resolvendo o problema da escassez de transporte) e transportando e vendendo os meios de produção necessários (resolvendo o problema do principal da aquisição de meios de produção, sobretudo o escravo africano). O suposto explicitado é o de que, com o negro africano, se fará a agricultura propriamente colonial.

Contudo, os índios deveriam ser persuadidos do valor da agricultura para as necessidades internas:

[...] quanto lhes será útil o honrado exercício de cultivarem as suas terras; porque por este interessante trabalho não só terão os meios competentes para sustentarem com abundâncias suas cases, e famílias; mas vendendo os gêneros, que adquirirem pelo meio da cultura, se aumentarão neles os cabedais à proporção das lavouras, $e$ plantações (O Diretório, apud Almeida, 1997, p. 195).

Tal propósito se combinava, aliás, com as medidas geopolíticas que diziam respeito à decisão de povoar a Colônia com os povos nela originados. Aqui, vigoraram medidas de emancipação formal dos índios aldeados e da utilização sistemática da miscigenação como instrumento de política populacional colonial. 
Essa estratégia fundamentará o conjunto de normas do Directorio, que se deve observar nas povoaçõens dos indios do Pará e do $\mathrm{Ma}$ ranhão, assinado por Francisco Xavier de Mendonça Furtado, em 3 de maio de 1757, e aprovado no Reino pelo Alvará de 17 de agosto de 1758. O Diretório dos Índios, como ficou conhecido esse estatuto, sistematizou uma série de alvarás e decretos expedidos desde a chegada de Mendonça Furtado, acrescendo as regras de fundação, funcionamento e gestão da nova estrutura em que deveriam se transformar os aldeamentos. Assim, confirmou a liberdade indígena decretada pelos Alvarás de 6 e 7 de junho de 1755 (Domingues, 2000, p. 69); transformou os aldeamentos em comunidades civis administradas por funcionários - os diretores -, aos quais competiam, inclusive, as operações de descimento; confiscou e redistribuiu a agentes coloniais, militares e famílias reinóis os bens das ordens religiosas, suas fazendas e rebanhos de gado; incentivou a miscigenação, incorporando o Alvará de 4 de abril de 1755, no qual se decretava "que os luso-brasileiros casados com índias não deviam ser discriminados, mas antes dignos do favor real" (Domingues, 2000, p. 72); regulamentou o uso e o pagamento da força de trabalho tutelada nos diretórios, mantendo basicamente as regras de repartimento tripartite entre administra- ção colonial, Igreja e colonos - nesse caso, mantendo a possibilidade, também regulamentada, da busca das "drogas do sertão" e indicou os passos para o desenvolvimento em geral, e da agricultura em particulardesde um amplo programa de educação, do que fazia parte desde a formação de hábitos de trabalho sedentário até a indicação de espécies silvestres a ser preferencialmente amansadas e de culturas que deveriam ser vistas como promissoras.

Além das normas do Diretório, que atuavam diretamente nas relações de produção, técnicas e sociais, a gestão pombalina interferiu na estruturação das relações de comércio através da criação da Companhia de Comércio do Grão Para e do Maranbão, fundada em 6 de junho de 1755, com direitos totais de monopólio sobre o comércio de mercadorias, entre as quais os escravos africanos.

Como discutido na introdução, o movimento de ideias e o vigor das ações implementadas no período têm colocado, para a historiografia, expectativas de desenvolvimento econômico, no que se refere: 1) ao crescimento e seus fundamentos mais abstratos - se indica mais produção e produtividade; 2) às mudanças estruturais da economia da Colônia - se indica revitalização da economia e estabelecimento da agricultura na base produtiva da Colônia, de modo que o crescimento da Colônia de- 
veria se fazer através do crescimento da sua componente agrícola a partir do reforço a plantation com base em escravos negros e da formação de um estrato camponês; 3) o desenvolvimento comercial que se espera da Companhia de Comércio deverá estar a serviço desses propósitos e, como tal, ser percebido como base da melhoria dos intercâmbios da Colônia com o resto do sistema.

Vejamos, à luz dos nossos resultados, um a uma dessas proposições.

\section{1_Sobre o crescimento econômico e seus fundamentos}

Nos primeiros 22 anos de vigência do Diretório até o encerramento das atividades da Companhia de Comércio, a economia colonial amazônica teve crescimento modesto de 1,54\% a.a. A produção cresceu a taxas de 2,99\% a.a., mais como um resultado do crescimento da população a 2,19\% a.a. que pelo incremento da produtividade que se fez a meros 0,78\% a.a.

As relações externas fizeram-se sob a égide de preços declinantes a $-1,41 \%$ a.a. no mercado mundial, tendência que, mediada pela nova institucionalidade da qual a Companhia é a referência fundamental, se refletiu em queda mais rápida no interior da Colônia, a $-1,51 \%$ a.a. De modo que, mesmo com a elasticidade-preço da produção exportada de $-0,47$ (para cada 1\% de elevação da quantidade exportada, uma redução de $-0,47 \%$ no preço no mercado mundial), o multiplicador $\mathrm{m}$ se manteve crescente, apesar do baixo ritmo de 0,1\% a.a. O que expressa melhora nas condições de formação do valor adicionado na Metrópole, que cresce a 1,66\% a.a., o dobro da dos agentes internos à Colônia: 0,82\%. Por seu turno, o crescimento da parcela dos impostos se faz à taxa de 2,85\% a.a. - a maior entre todas (Tabela 1).

\section{2_Sobre os propósitos de implantar uma economia de base agrícola}

É recorrente a menção aos esforços da gestão pombalina na aquisição de escravos negros e na introdução de variedades novas de produtos agrícolas, como arroz e algodão, no Grão-Pará. Não obstante, merece tratamento a constatação de que a produção regional manteve nesse período o perfil herdado do período anterior, no qual se verifica a dominância do extrativismo de coleta. Mais precisamente, o valor dos produtos do extrativismo de coleta cresceu no período a 1,44\% a.a. ao passo que o da agropecuária cresceu em ritmo um pouco menor, de 1,23\% a.a.

A rigor, as atividades agrícolas iniciam o período de vigência do monopólio da Companhia com participação importante, de $30 \%$, no valor da produção da Colônia. 
Essa proporção cai até meados dos anos sessenta, quando se aproxima de 10\%. A partir daí, recupera-se até atingir o patamar dos primeiros anos do período. A produção agrícola processada na Colônia, como o açúcar e a aguardente, que apresentara relativa importância no início do período, perdeu significado ao longo do tempo. A produção animal, por sua vez, cresceu em importância, apesar de lentamente.

Por outro lado, se desdobramos as atividades do extrativismo em extrativismo de coleta (as "drogas do sertão") e madeireiro, o primeiro tem dominância quase completa (Gráfico 2).

\section{Gráfico 2_ Participação relativas das diversas atividades nas exportações da Colônia} do Grão-Pará, 1755 a 1777 ( $\%$ do total exportado)

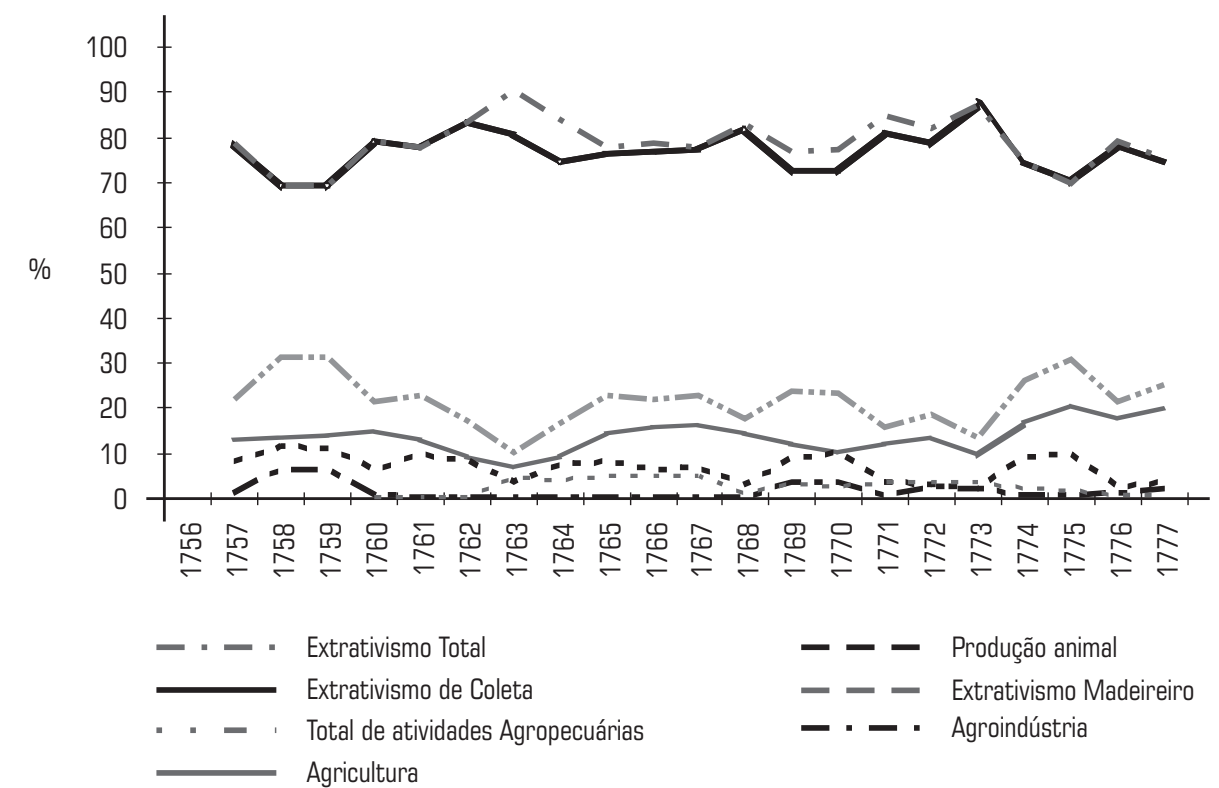

Fonte: Dias (1970, p. 316-360).

Observação metodológica: Tomaram-se as informações anuais fornecidas pelo autor, produto a produto, por tipo de rubrica, se "Companhia" ou se "Colonos", e formou-se um banco de dados próprio, tabulado com os recursos do SPSS. Por isso, os valores agregados apresentam diferença em relação ao próprio trabalho fonte, em várias situações por equívocos de soma. Tivemos o cuidado de, nessas situações, cotejar com outras fontes, principalmente Carreira (1988). 


\section{3_ Sobre as mudanças estruturais}

Os dados do período nos permitem observações importantes sobre a estruturação da base produtiva. Primeiro, há indicações muito fortes da existência e do crescimento de uma estrutura de produção relevante na Colônia, além da representada pelos colonos escravistas e pelos Diretórios. É o que informam os resultados da Tabela 2, quando adequadamente observados.

Manuel Nunes Dias, em monumental trabalho (Dias, 1970) que relaciona produto a produto, ano a ano, os embarques em Belém da Companhia de Comércio do Grão-Pará e do Maranhão, rotulou as mercadorias pelos seus titulares, separando-as em dois tipos: àquelas adquiridas pela própria empresa atribuiu a categoria de " $\mathrm{Com}$ panhia" e às outras atribuiu a categoria de "Lavradores", correspondente aos agentes que vimos designando de "Colonos". Nu- ma primeira verificação, constata-se uma diferença muito grande entre o primeiro quinquênio e os demais na participação relativa desses grupos: de aproximadamente $51 \%$ e $49 \%$, respectivamente, a "Companhia" passa para proporções em torno de $85 \%$, e os "Colonos", $15 \%$. O próprio Manuel Nunes Dias esclarece a diferença por viés de conduta dos "Colonos", os quais, favorecidos por uma carta régia que lhes facultava o direito de consignar sua produção exportável a seus comissários do reino, na forma do que dispunha o parágrafo 27 do estatuto da Companhia. Os "Colonos"

\section{[...] transformaram o favor régio numa artimanha, porquanto, debaixo de seus no- mes puderam os corretores particulares fa- zer o comércio de gêneros em evidente pre- juizo da Companhia, sem que a Junta da Administração conseguisse averiguar e ata- lhar o contrabando (Dias, 1970, p. 363).}

Tabela 2_ Participação dos titulares das cargas assumidas em Belém pela Companhia

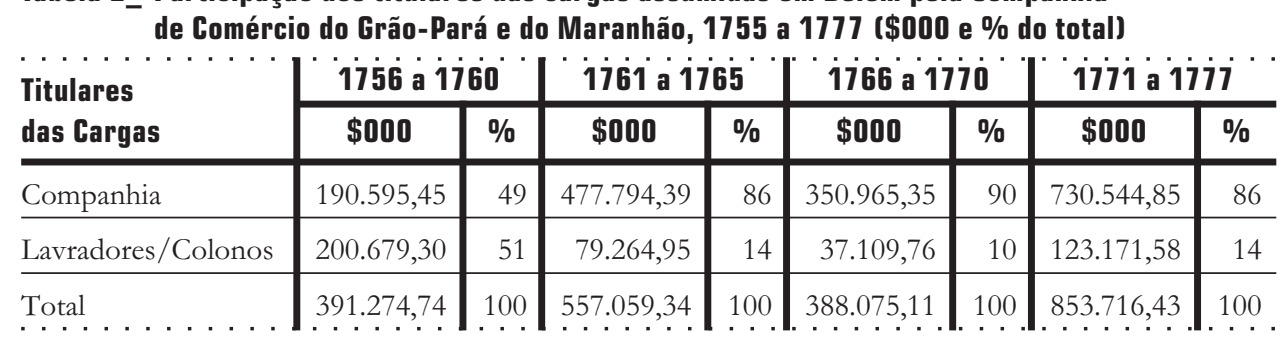

Fonte: Tabela A-2 e Tabela A-3. 
A pedido da Companhia, em 26 de fevereiro de 1760 , estabeleceram-se normas para que apenas a produção dos Colonos passível de comprovação fosse aceita.

Daí, as seguintes ilações:

a. a produção embarcada até 1759 sob a titularidade da "Companhia" provinha das estruturas produtivas que disso não poderiam se furtar, os Diretórios - estruturas que, como ex-aldeamentos, não obstante sua recente designação civil de vila e lugar, continuavam, como bem anota Azevedo (1930, p. 340), sob estrita tutela da administração colonial -, e expressam, por isso, o peso relativo mais próximo do real que se pode mensurar, desse segmento na produção exportável total da Colônia;

b. a estrutura produtiva dos colonos de origem europeia, dependentes do trabalho escravo negro, na agricultura, e da repartição do trabalho dos índios aldeados, no extrativismo, fortalecida no período pela chegada de novas levas de casais açorianos, pelo financiamento na aquisição de escravos e pela absorção das fazendas das ordens religiosas (Azevedo, 1930, p. 340), terá seu peso real expresso nos quinquênios pós-1760, quando só puderam transacionar a própria e efetiva produção;

c. montaram-se duas estruturas de transação no período: até 1759 , "corretores particulares" fizeram dos "Colonos" seus intermediários, driblando a Companhia; a partir daí, esses mesmos agentes fizeram da "Companhia" a intermediação necessária para acessarem o mercado mundial;

d. se existiram "corretores particulares" que intermediavam produtos, quer dizer, se existiram estruturas mercantis internas à Colônia, existiram necessariamente produtores das mercadorias que intermediavam, os quais não se ajustavam nem nas estruturas dos Diretórios nem nas dos colonos.

A participação desses produtores invisíveis pode ser mensurada, posto que igual a dos "corretores particulares" no eufemismo de Manoel Nunes Dias, aos quais atribuiremos a condição de comerciantes não reconhecidos, estes constituindo o outro polo de um par estrutural com os produtores invisivivis. A parcela intermediada por esses comerciantes não reconhecidos, precisamente igual a dos 
seus supridores, os produtores invisiveis da Colônia, terá sido igual ao total exportado, menos a produção dos Diretórios, menos ainda a verdadeira produção dos Colonos. A produção dos Diretórios até 1760 é igual ao que foi exportado sob a rubrica "Companhia”. A partir de 1760, é igual à percentagem média da rubrica "Companhia" no total da produção exportada até 1760 - sublinhe-se, a participação histórica conhecida dos Diretórios no total da exportação - vezes o total da produção exportada dos anos posteriores a 1760. A verdadeira produção dos Colonos será, após 1760, o que foi exportado sob a rubrica "Colonos"; antes de 1760, a participação relativa média da rubrica "Colonos" no total da produção exportada, após 1760, vezes o total da produção exportada dos anos anteriores a 1760.

Aplicado esse algoritmo ao nosso banco de dados (observação metodológica da Tabela 2), chegamos ao resultado apresentado nos Gráficos 3 e 4.

\section{Gráfico 3_ Participação relativa das diversas estruturas produtivas da Colônia do Grão-Pará,} 1755 a 1777 (\% do valor exportado total, médias móveis bianuais)

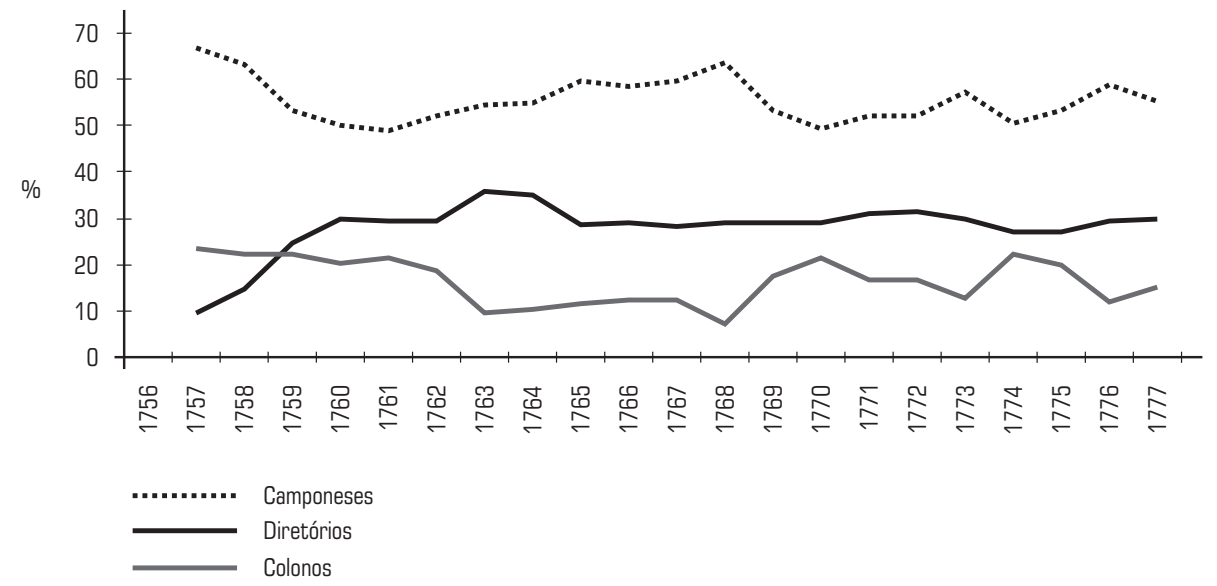

Fonte: Tabela A-2 e Tabela A-3. 


\section{Gráfico 4_ Participação relativa das diversas atividades na produção exportada dos camponeses da Colônia do Grão-Pará, 1755 a 1777 \\ (\% do total exportado, médias móveis bianuais)}

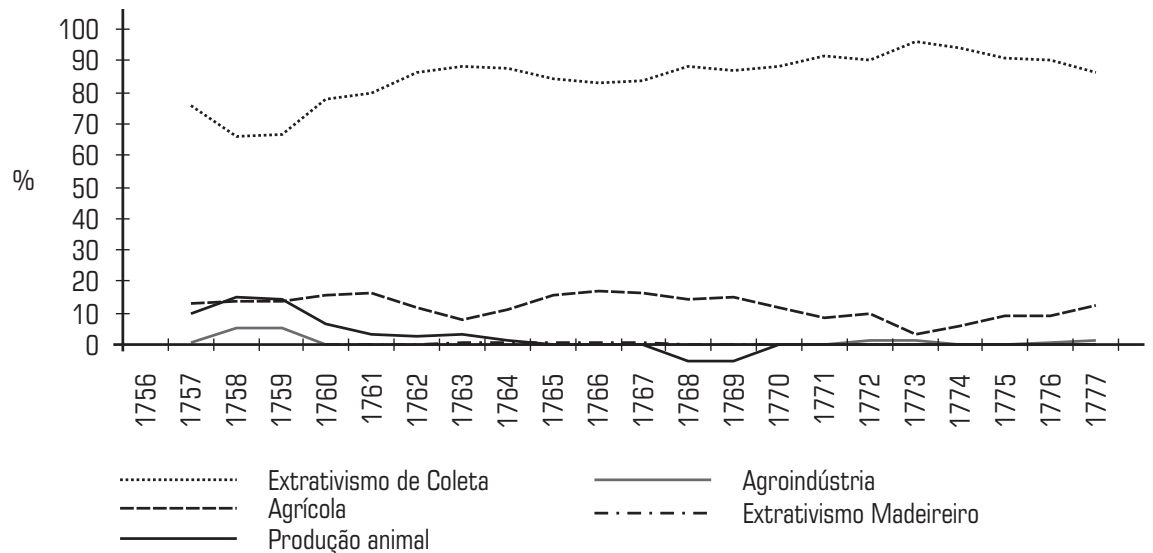

Fonte: Tabela A-2 e Tabela A-3.

Um primeiro resultado é o de que, acima da metade da produção da Colônia, ao longo do período pombalino, não se explicaria pelas estruturas, produtiva e comercial, "oficiais" da Colônia (Gráfico 3). Isso dá uma indicação robusta da importância dos produtores invisiveis, os quais entendemos constituir um campesinato.

Todavia, não se trataria de um campesinato agrícola, como indica Ciro Flamarion Cardoso: a produção exportada a ele atribuível é basicamente derivada de extrativismo de coleta, cujo valor cresceu, ademais, a 2,3\% a.a., de modo que sua expressão cresce no período de aproximadamente $70 \%$ para algo próximo de $90 \%$ no valor da produção total desses produtores. A produção agrícola exportada associada a esse campesinato, por seu turno, deverá ter decrescido a -3\% a.a, de modo que sua participação na exportação total do final do período ficou em torno 9\% (Gráfico 4).

Por sua vez, o perfil da produção dos colonos altera substancialmente no período pombalino: os produtos agrícolas in natura, que pouco representavam no início do período, chegam ao final com participação próxima de $50 \%$, resultado de um forte crescimento de 10,7\% a.a; a produção animal cresce notavelmente a 7,3\% a.a, chegando a representar algo próximo de $20 \%$; a agroindústria teve um momento impor- 
tante no meio termo, mais caiu a quase nada no final do período - o contrário da produção madeireira exportável que cresceu precisamente nessa fase final; o extrativismo de coleta, por seu turno, caiu sistemática e fortemente a $-9,1 \%$ a.a, na pauta produtiva desse segmento da produção colonial por todo o período em questão (Gráfico 5).

No que refere aos Diretórios, a participação do extrativismo de coleta se manteve em torno de $70 \%$, e a agricultura aumentou sua expressão, chegando sua participação nos últimos cinco anos a 20\%. Notável o desenvolvimento do extrativismo madeireiro que, não obstante as fortes oscilações, se fez presente de modo importante em vários subperíodos (Gráfico 6).

\section{4_ A Colônia do Grão-Pará após Pombal (1778-1722)}

Há dois subperíodos a tratar após a gestão do marquês de Pombal. O primeiro se estende do final do reinado de D. José I e o imediato fechamento da Companhia de Comércio do Grão-Pará e do Maranhão, em 1778, até a extinção dos Diretórios, em 1798. O segundo subperíodo seguirá de 1799 até o final do período colonial, em 1822.

\section{Gráfico 5_ Participação relativas das diversas atividades na produção exportada dos colonos, da Colônia do Grão-Pará, 1755 a 1777 \\ (\% do total, médias móveis bianuais)}

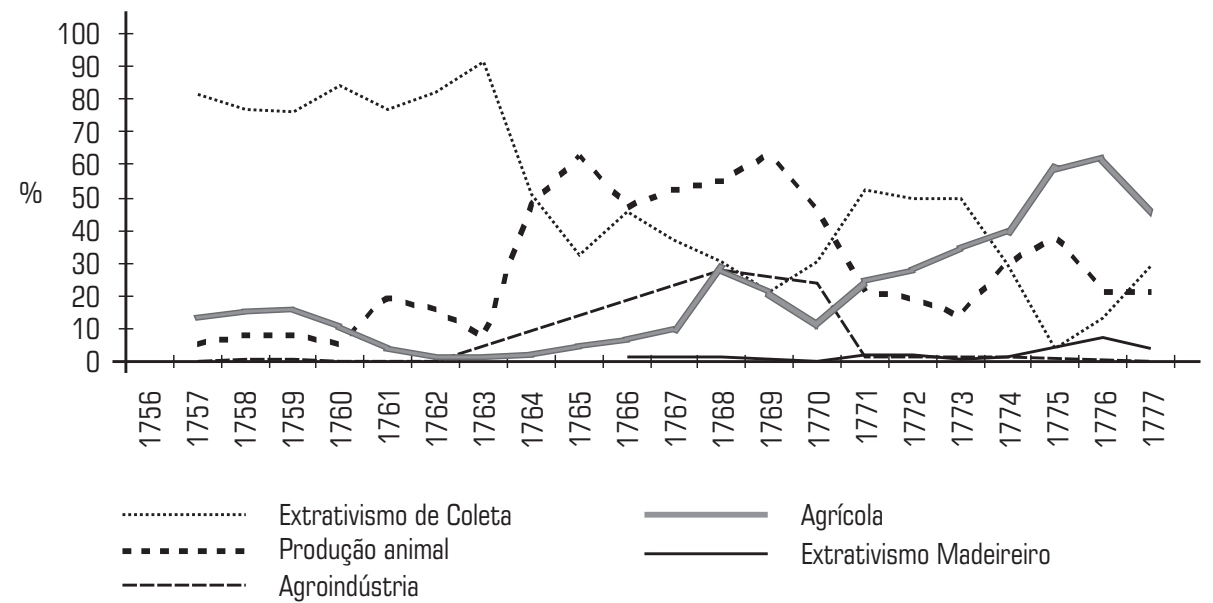

Fonte: Tabela A-2 e Tabela A-3. 


\section{Gráfico 6_ Participação relativa das atividades na exportação dos Diretórios da Colônia do Grão-Pará, 1755 a 1777 \\ (\% do total, médias móveis bianuais)}

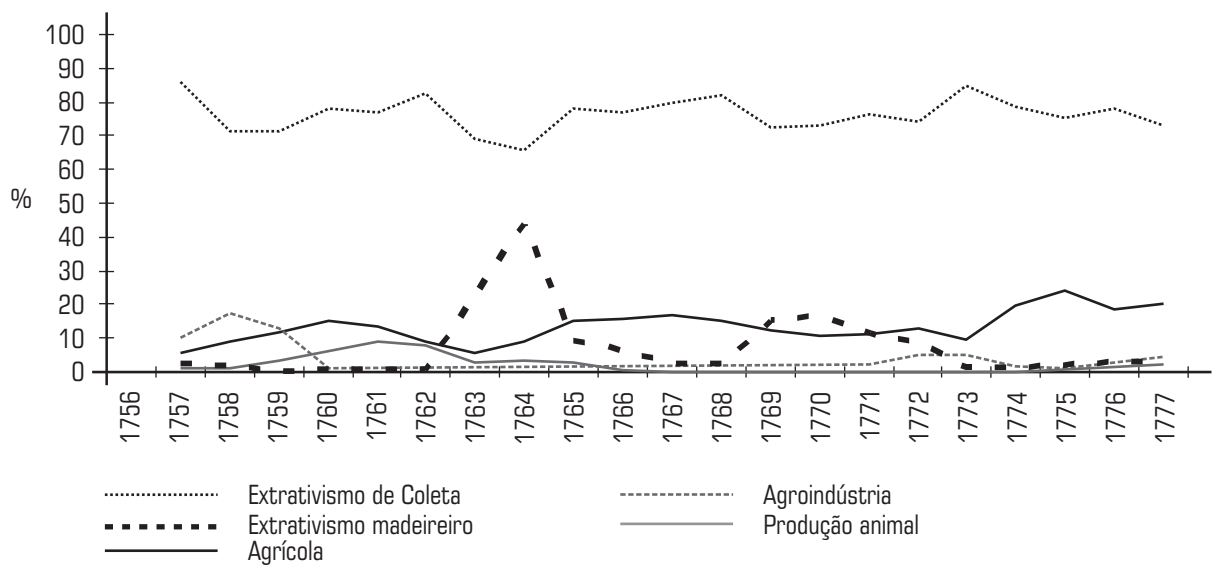

Fonte: Tabela A-2 e Tabela A-3.

\section{1_ Do fim da Companhia ao fim dos Diretórios - 1717 a 1789}

Os primeiros cinco anos da gestão pombalina, nos quais se forjaram as reformas que marcaram os tempos seguintes, foram anos de crise de um sistema que já tinha história, que já seguia um trajeto no qual mostrara seu potencial na perspectiva do Império Colonial. As reformas pombalinas não ocorrem para, enfim, montar uma economia extrativa, como sugere Almeida (1997, p. 227-235). Fizeram-se para superar o que se conseguia ver dos gargalos revelados por momento crítico daquela economia, que, não obstante estranha, posto que baseada em extrativismo, já tinha um passado do qual o presente era dependente. $\mathrm{Na}$ busca de superação, aí sim, procurou-se validar um projeto institucional de "criação" de uma agricultura eficaz - uma retomada do projeto agrícola civilizatório dos primórdios da Colônia, com nuances novas que abrigavam um campesinato.

Como parte da estratégia, tomaramse medidas que incentivavam a miscigenação na constituição de famílias nucleadas, as quais aceleram a criação de um número crescente de famílias com dupla característica, a saber: elas detinham o conhecimento índio da natureza circundante e, ao mesmo tempo, se reproduziam atendendo às 
necessidades e aos valores europeus. Tais famílias - nem índias, nem brancas: caboclas - têm endogenamente as precondições de conhecimento para viver e produzir fora dos Diretórios, fora, portanto, do controle do sistema produtivo vigente. Pois, ao contrário das famílias dos colonos brancos, elas poderiam lidar sem dificuldades com o meio ambiente e, por outra parte, só com muita dificuldade poderiam viver sem mercadorias europeias. Com tais atributos, essas seriam famílias que poderiam reproduzir-se apenas do trabalho dos seus membros - essa reprodução pressupondo, todavia, a sua inserção, como unidade irredutível e nuclear, no mundo da mercadoria. Tudo leva a crer que, a partir daí, se pode falar de um campesinato em formação, típico amazônico, que veio a se estabelecer como o campesinato-caboclo próprio da região.

A esse campesinato-caboclo atribuímos a produção exportável não explicada nem pelos aldeamentos nem pelos Diretórios, nem tampouco pelas unidades produtivas escravistas dos colonos brancos. Ademais, a colocação dessa produção no mercado pressupôs uma classe mercantil gradativamente formada na Colônia, originária de uma mistura de colonos, funcionários, militares e aventureiros, os quais puderam se colocar como concorrentes diante do sistema de monopólio oficial porque existia uma produção livre, a produção camponesa-cabocla, que não poderia ser controlada pela Companhia na fonte. Assim, camponeses-caboclos e comerciantes locais (regatões e aviadores) se desenvolveram como uma unidade estrutural - parte do mesmo processo evolutivo ao longo da segunda metade do século XVIII, vindo a se tornar a base da economia extrativa a partir de então.

Assim, o período pós-pombalino conta com a estrutura produtiva dos Colonos, dos Camponeses-Caboclos e dos Diretórios, estes últimos em nítida decadência, conforme se pode deduzir da Tabela 3. Da diluição dos Diretórios se alimenta a expansão da estrutura camponesa, em processo que João Lúcio D’Azevêdo viu assim:

[...] em decair progressivo foram os antigos estabelecimento dos regulares, sob o regime laical, arrastando uma lamentável existência, até aos derradeiros anos do século [XVIII]. [...] Povoavam-se os matos de trânsfugas, enquanto os lugares da habitação ficavam ermos (Azevedo, 1930, p. 377).

Com a expansão da base camponesa-cabocla, cresce seu par estrutural, o capital mercantil endógeno à Colônia, cujos agentes visíveis são os regatões (comerciantes móveis que utilizam barcos em seu 
Tabela 3_ Participação dos ex-Aldeamentos nas exportações totais de cacau em anos escolhidos (em libras)

\begin{tabular}{|c|c|c|c|}
\hline Ano & $\begin{array}{l}\text { Ex-aldeamentos } \\
\text { (A) }\end{array}$ & $\begin{array}{c}\text { Total das exportações } \\
\text { (B) }\end{array}$ & $\begin{array}{c}(A) /(B) \\
(\%)\end{array}$ \\
\hline 1761 & 209.648 & 1.153 .888 & 18 \\
\hline 1764 & 222.985 & 1.045 .839 & 21 \\
\hline 1768 & 386.834 & 1.311.171 & 30 \\
\hline 1769 & 215.047 & - & \\
\hline 1770 & 101.363 & 1.639 .977 & 6 \\
\hline 1771. & 109.801 & 1.233 .387 & 9 \\
\hline
\end{tabular}

Fonte: Alden (1974, p. 53-60). Tabulação do autor.

deslocamento), os marreteiros (pequenos comerciantes do interior, dependentes de suprimentos de comerciantes maiores) e os aviadores (comerciantes maiores sediados em Belém, supridores e financiadores de regatões e marreteiros). Tocantins expõe o arranjo do seguinte modo:

\section{[...] A canoa veio criar uma figura que até} hoje perdura na paisagem social amazônica [...]: o regatão. Evoluindo do tipo comum de comerciante para um estágio de trabalho mais desenvolvido, mais complexo [...], o ofício foi primeiro do português e depois acabou por ser, já no século XIX, ofício de preferência do turco. [...] o método de negociar no interior era quase o mesmo dos dias atuais. Os comerciantes em Belém enviavam mercadorias para as vilas do interior [...] e (citando Baena (1938)) [...] em troca recebiam os produtos naturais sacados dos matos e os produtos da indústria. Na operação mercantil com os lavradores, estes recebem o valor venal, parte em moeda, parte em fazendas e viveres (Tocantins, 1960, p. 123-125).

Sobre essas bases estruturais, produtivas e transacionais, e sem a governança da Companhia e seu mandato de monopólio nas relações mercantis externas, a economia colonial como um todo (Y\$) mais que dobra a taxa de crescimento para $3,77 \%$, entre 1778 e 1798, comparativamente ao período anterior. Evolução em parte explicada pelo crescimento da população a 2,08\%, em parte por preços em recuperação no mercado externo, a 2,54\% a.a., visto que a produtividade física per capita cai a $-0,87 \%$. A formação de valor adicionado na Metrópole cresce a ritmo duplamente acelerado, $4,12 \%$ a.a., do valor retido pelos agentes 
internos à Colônia a velocidade de 3,86\% a.a., mais de quatro vezes a taxa precedente, a par de um crescimento mais lento da massa de impostos a 1,19\% a.a.

Distintivo do período, o crescimento da exportação de produtos agropecuários se fez à taxa de 7\% a.a. Convém indicar que tal performance se explicou pelo crescimento da produção física a $2,2 \%$ e, sobretudo, pelo crescimento dos preços a $4,8 \%$ a.a. Note-se que se trata de ritmos praticamente inversos aos que se verificam no período imediatamente anterior (o período "propriamente pombalino") para as duas variáveis, quando a pífia performance de crescimento do valor exportado a 1,2\% a.a. se explica sobretudo pela queda nos preços a $-5,1 \%$ a.a., contra-arrestando o crescimento na quantidade exportada de 6,7\% a.a. A expansão da capacidade produtiva que isso representa, crédito do período pombalino, só se realiza como expansão da receita na fase posterior, com a recuperação dos preços (Gráfico 7).

\section{Gráfico 1_ Evolução das quantidades e preços da produção extrativa e agropecuária de exportação da economia colonial amazônica 1720 a 1820 (em toneladas e \$000/tonelada, médias móveis quinquenais)}

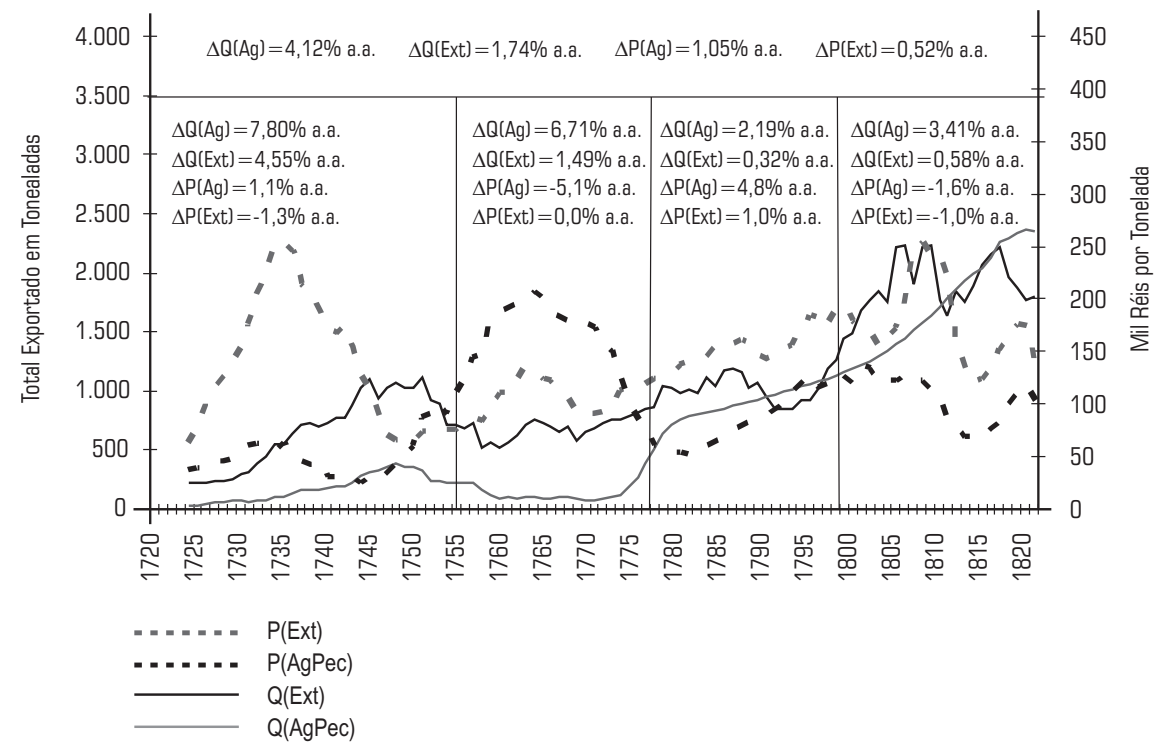

Fonte: Tabela A-1. 
E assim, na média dos três últimos anos do período pombalino, o valor exportado da agropecuária representava 23\%, um recuo em relação aos $31 \%$ que representara na média dos três primeiros anos do período, isto é, 22 anos antes. Agora, precisamente 22 anos depois, no final do período dos Diretórios, a agricultura passou a representar $46 \%$ do valor exportado - o dobro do que fora no final do período sob influência direta da gestão pombalina (Gráfico 8).

\section{2_ Do fim dos Diretórios ao fim da Colônia - 1799 a 1820}

Diferentemente do desempenho positivo do período anterior para as principais variáveis da economia colonial amazônica, nesse turno se fazem sentir as marcas da crise que assola nesse interregno todo o sistema colonial português (Novais, 1986). O valor da produção da Colônia no mercado mundial cai, entre 1799 e 1820, a $-2,19 \%$ a.a., resultado da queda nos preços a -3,97\% a.a., compensada por um le-

Gráfico 8_ Evolução da participação relativa dos grupos de produtos da pauta de exportação da economia colonial amazônica 1720 a 1820

(\% de X\$, médias móveis quinquenais)

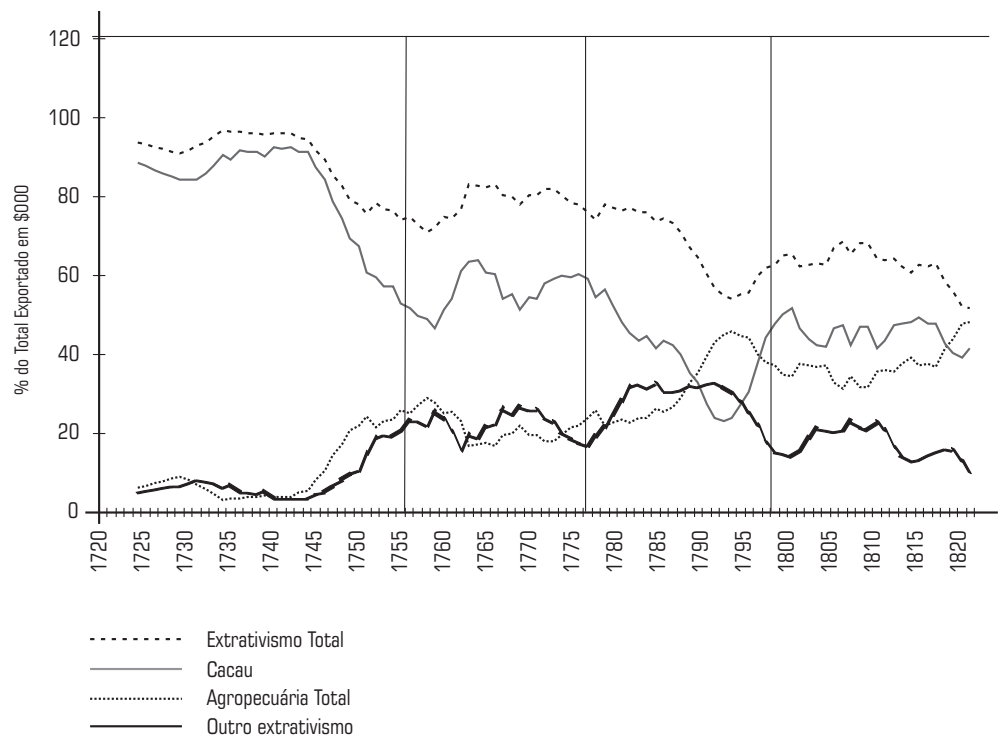

Fonte: Tabela A-1. 
ve incremento da produtividade per capital de $0,75 \%$ a.a. e um incremento demográfico de $1,1 \%$ a.a. Por outro lado, a parcela de valor adicionado na Metrópole cai a $-5,09 \%$ a.a., enquanto o valor retido na Colônia cresce positivamente, apesar da baixa taxa de $0,11 \%$ a.a. De modo que, no final desse período, a participação relativa da retenção de valor na Metrópole reflui a níveis semelhantes ao encontrado em 1750, por Francisco Xavier de Mendonça Furtado, nos primórdios da gestão pombalina.

Há, todavia, distinção fundamental no plano estrutural da produção. Com o fim dos Diretórios, a Colônia do Grão-Pará passou a se assentar em apenas duas grandes estruturas produtivas: a fundamentada no campesinato-caboclo, que, em estreita relação com os regatões e seus aviadores, exportam dominantemente produtos extrativos, e a dos colonos escravistas, que exportam dominantemente produtos agropecuários. Eliminada a reserva de força de trabalho hábil para a coleta, tutelada para concessão aos colonos pelos Diretórios, e conformadas definitivamente estruturas camponesas que internalizam conhecimentos e habilidades índias, chaves da economia extrativista, reduz a capacidade dos colonos na produção das "drogas do sertão", crescendo em compensação sua capacidade de produção agrícola.
Com efeito, a quantidade exportada dos produtos agropecuários cresce no período a 3,4\% a.a. Dado que os preços caem a - $1,6 \%$ a.a., o crescimento da receita de exportação desses produtos se faz a um ritmo mais baixo, de 1,8\% a.a. Não obstante tratar-se de ritmo bem superior ao da produção extrativista, cuja capacidade produtiva se expande a $0,6 \%$ a.a., com preços decrescentes a $-1 \%$ a.a., tal evolução não foi suficiente para contestar o domínio do extrativismo de coleta da economia, setor produtivo que representava $61 \%$ na média dos últimos cinco anos do período colonial.

\section{5_Considerações finais}

O período pombalino não se demonstrou ser o momento em que, enfim, se estabeleceram os fundamentos da economia amazônica, nem tampouco o evento genial perdido - para o qual não se verificariam consequências relevantes na perspectiva da constituição da economia regional. O que vimos indica ser essa fase, com o "Diretório dos Índios" e a "Companhia", um fundamental e criativo momento de uma trajetória já iniciada antes, com o "Regimento das Missões", a qual, por uma parte se impôs ao protagonismo reformador que marcou o período, por outra, dele recebeu condicionantes que marcaram indelevelmente os próximos períodos. 
Os primeiros cinco anos da gestão pombalina foram de crise de um sistema que já tinha história, que já mostrara seu potencial. De modo que as providências e medidas foram tomadas, antes, para superar o que se conseguia ver dos gargalos expostos por momento crítico daquela economia, que, não obstante estranha, pois baseada em extrativismo, se mostrara, de muitos modos, promissora. Além da instabilidade fiscal, um dos problemas a superar, o da

[...] preservação do exclusivo metropolitano [...que...] vai num crescendo para atingir um climax no período da administração pombalina (Novais, 1986, p. 176).

$\mathrm{Na}$ economia amazônica sob o Regime das Missões, a participação do valor apropriado na Metrópole se mostrara sistematicamente inferior à parcela apropriada na Colônia.

Na busca de soluções, ao lado dos mecanismos que invertem rapidamente essa situação, e mantém a participação crescente da Metrópole no valor da produção colonial, tem lugar um projeto institucional de "criação" de uma agricultura eficaz uma retomada do projeto agrícola civilizatório que marcara o início da Colônia. Apesar de o passado extrativista se afirmar na realidade da gestão pombalina, o projeto agrícola produz heranças, planta sementes.
Nas fases finais do período colonial, a par da crise manifesta nas relações externas, o que se tem internamente na Amazônia é uma economia estruturalmente ímpar, com capacidade crescente de lidar equilibradamente com dois exigentes departamentos, quais sejam: um extrativista associado ao bioma único e altamente complexo, e outro agrícola no contexto edafo-climático, também único da região. Os sistemas de produção nesses dois departamentos exigiram processos não triviais de aprendizado - o que propriamente qualificaram a especificidade da trajetória. Tanto foi necessário o aprendizado difuso que permitiu acessar sistematicamente e com produtividade crescente o bioma originário amazônico - só possível pelo estabelecimento de estrutura camponesa que herdara as habilidades e os conhecimentos índios e as associaram a padrões de necessidades e conhecimentos europeus - quanto também o que permitiu estabelecer uma agricultura adaptada às condições peculiares da região.

Não coincidentemente, essas são precisamente as questões maiores quando hodiernamente se discute as alternativas de desenvolvimento (com esperança de sustentabilidade) para a Amazônia. 


\section{Referências bibliográficas}

ALDEN, D. O significado da produção de cacau na região Amąônia. Belém: NAEA-UFPa, 1974.

ALMEIDA, R. H. O Diretório dos indios: um projeto de civilização no Brasil do século XVTII. Brasília: Editora Universidade de Brasília, 1997.

AZEVEDO, J. L. D. Os jesuitas no Grão-Pará: suas missões e a colonização. Coimbra, Ed. Universitária, 1930.

AZEVEDO, J. L. D. Os jesuítas no Grão-Pará: suas missões e a colonização. Belém, SECULT, 1999.

BARATA, Manoel. A antiga produção e exportação do Pará. In: BARATA, M. Formação Histórica do Pará. Belém: UFPa, 1973.

CARDOSO, C. F. Economia e sociedade em áreas periféricas: Guiana Francesa e Pará (1750-1817). Rio de Janeiro: Edição Graal, 1984

CARDOSO, C. F. Crise do colonialismo luso na América Portuguesa - 1750/1822. In: LINHARES, M. Y. História Geral do Brasil. Editora Campos, 1990. p. $89-110$.

CARREIRA, A. A Companbia Geral do Grão-Pará e Maranbão: o comércio intercontinental Portugal-ÁfricaBrasil na segunda metade do século XVIII. São Paulo: Nacional, 1988.
COSTA, O. O Povoamento da Amazônia. Revista Brasileira de Estudos Políticos, Belo Horizonte, UFMG, n. 27, 1969.

COSTA, F. de A. AmazonienBauern, Märkte und

Kapitalakkumulation.

Saarbrücken-Forlauderdale, Verlag Breitenbach Publishers, 1989

DIAS, M. N. Fomento e mercantilismo: a Companhia Geral do Grão Pará e Maranhão (1755-1778). Belém: UFPA, 1970.

PADRE JOÃO DANIEL, J. Tesouro descoberto no máximo rio Amazonas. Rio de Janeiro: Contraponto, 2004.

DOMINGUES, A. Quando os indios eram vassalos: Colonização e relações de poder no Norte do Brasil na segunda metade do século XVIII. Lisboa: Comissão Nacional

Comemorações dos

Descobrimentos Portugueses, 2000

FALCON, F. J. C. A época pombalina. São Paulo: Ática, 1982.

FURTADO, C. Formação econômica do Brasil. São Paulo: Companhia Editora Nacional, 1976.

INSTITUTO BRASILEIRO DE GEOGRAFIA E ESTATÍSTICA IBGE. Estatísticas Históricas do Brasil: Séries Econômicas e Sociais 1550 a 1988. Rio de Janeiro, 1990.
MARANHÃO, M. F. O moinho e o engenho: São Paulo e Pernambuco em diferentes contextos e atribuições no Império Colonial Português 1580-1720. 2006. Tese (Doutorado em História) - Departamento de História da Faculdade de Filosofia, Letras e Ciências Humanas da Universidade de São Paulo, São Paulo, 2006.

MENDONÇA, M. C. A Amazônia na Época Pombalina. Rio de Janeiro: Imprensa Nacional, 1963.

NEVES, A. B. Os soldados de Cristo na terra dos papagaios. Colonialismo e repressão cultural. Rio de Janeiro, Forense-Universitária, 1987.

NOVAIS, F. A. Portugal e Brasil na crise do antigo sistema colonial (1777-1808). São Paulo: Hucitec, 1986.

PRADO JR., C. História econômica do Brasil. São Paulo: Brasiliense, 1987.

REIS, A. C. F. O processo bistórico da economia amazônica. Rio de Janeiro: Imprensa Nacional, 1944.

SANTOS, R. História econômica da Amazônia (1800-1920). São Paulo: T. A. Queiroz, 1980.

SHIKIDA, C. D. Apontamentos sobre a economia política da Companhia Geral de Comércio do Grão-Pará e Maranhão. Revista de
Economia e Administração, v. 6, p. 175-190, 2007.

SODRÉ, N. W. Formação bistórica do Brasil. Rio de Janeiro: Bertrand Brasil, 1987.

TOCANTINS, L. Amazônia: Natureza, Homem e tempo. Rio de Janeiro: Conquista, 1960.

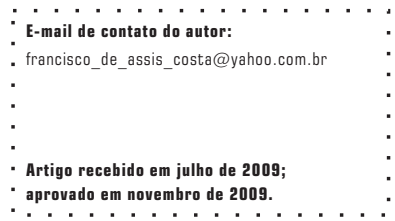


Anexos

Tabela A-1_Principais variáveis da economia colonial do Grão-Pará

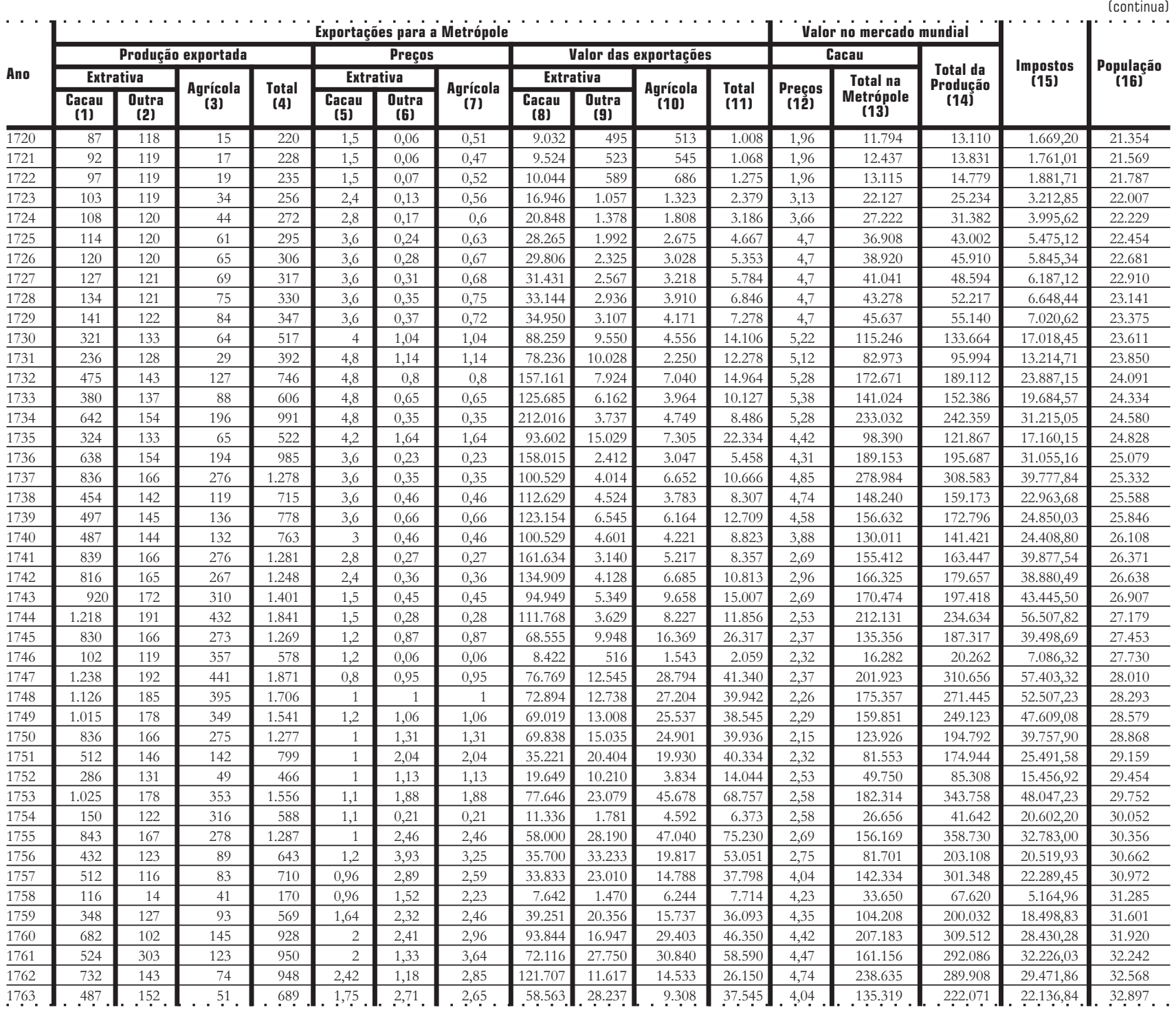


Tabela A-1_Principais variáveis da economia colonial do Grão-Pará

\begin{tabular}{|c|c|c|c|c|c|c|c|c|c|c|c|c|c|c|c|c|}
\hline \multirow{4}{*}{ Ano } & \multicolumn{11}{|c|}{ Exportaçóes para a Mietrópole } & \multicolumn{3}{|c|}{ Valor no mercado mundial } & \multirow{4}{*}{$\underset{\text { Impostos }}{\text { Imp }}$} & \multirow{4}{*}{$\begin{array}{c}\text { População } \\
\text { (16) }\end{array}$} \\
\hline & \multicolumn{4}{|c|}{ Produção exportada } & \multicolumn{3}{|c|}{ Preços } & \multicolumn{4}{|c|}{ Valor das exportaçóes } & \multicolumn{2}{|c|}{ Cacau } & \multirow{3}{*}{$\begin{array}{c}\text { Total da } \\
\text { Produção } \\
\text { (14) }\end{array}$} & & \\
\hline & \multicolumn{2}{|c|}{ Extrativa } & \multirow{2}{*}{$\underset{\text { (3) }}{\text { Agrícola }}$} & \multirow{2}{*}{$\begin{array}{l}\text { Total } \\
\text { (4) }\end{array}$} & \multicolumn{2}{|c|}{ Extrativa } & \multirow{2}{*}{$\begin{array}{c}\text { Agrí́cola } \\
\text { (7) }\end{array}$} & \multicolumn{2}{|c|}{ Extrativa } & \multirow{2}{*}{$\begin{array}{c}\text { Agrí́cola } \\
\text { (10) }\end{array}$} & & & Total na & & & \\
\hline & $\begin{array}{l}\text { Cacau } \\
\text { (1) }\end{array}$ & $\begin{array}{c}\text { Outra } \\
\text { (2) }\end{array}$ & & & $\begin{array}{c}\text { Cacau } \\
(5)\end{array}$ & $\begin{array}{c}\text { Outra } \\
\text { (6) }\end{array}$ & & $\begin{array}{c}\text { Cacau } \\
\text { (8) }\end{array}$ & $\begin{array}{c}\text { Outra } \\
\text { (9) }\end{array}$ & & $\begin{array}{l}\text { lotal } \\
\text { (11) }\end{array}$ & $\begin{array}{l}\text { Preços } \\
\text { (12) }\end{array}$ & $\begin{array}{c}\text { Metrópole } \\
\text { (13) }\end{array}$ & & & \\
\hline 764 & 475 & 180 & 100 & 754 & 1,5 & 1,78 & 3,01 & 49.022 & 21.995 & 20.703 & 42.698 & 3,5 & 114.388 & 214.020 & $24.618,65$ & 33.229 \\
\hline 1765 & 459 & 216 & 119 & 794 & 1,5 & 1,56 & 2,46 & 47.417 & 23.161 & 20.092 & 43.253 & 3,39 & 107.236 & 205.056 & $26.419,06$ & 33.565 \\
\hline 1766 & 464 & 163 & 102 & 730 & 1,5 & 2 & 2,62 & 47.915 & 22.517 & 18.402 & 40.919 & 3,61 & 115.247 & 213.668 & $23.663,15$ & 34.566 \\
\hline 1767 & 424 & 266 & 122 & 812 & 1,5 & 1,31 & 2,5 & 43.811 & 23.991 & 20.975 & 44.966 & 4,42 & 128.963 & 261.325 & $27.751,82$ & 35.597 \\
\hline 1768 & 595 & 220 & 60 & 876 & 1,5 & 1,35 & 2,4 & 61.461 & 20.528 & 9.953 & 30.481 & 5,38 & 220.630 & 330.048 & $28.525,35$ & 36.658 \\
\hline 1769 & 14 & 47 & 7 & 68 & 1,5 & 0,42 & 2,73 & 1.446 & 1.346 & 1.379 & 2.725 & 4,85 & 4.687 & 13.521 & $2.683,87$ & 37.752 \\
\hline 1770 & 744 & 312 & 65 & 1.122 & 1,5 & 1,21 & 2,59 & 76.872 & 26.133 & 11.650 & 37.783 & 4,63 & 237.324 & 353.970 & $36.942,45$ & 38.877 \\
\hline 1771 & 560 & 232 & 144 & 936 & 1,5 & 1,73 & 2,26 & 57.815 & 27.665 & 22.442 & 50.106 & 4,52 & 174.334 & 325.425 & $30.772,88$ & 40.037 \\
\hline 1772 & 790 & 146 & 177 & 1.113 & 1,5 & 1,97 & 1,58 & 81.543 & 19.801 & 19.262 & 39.063 & 4,42 & 240.029 & 355.014 & $34.494,45$ & 41.231 \\
\hline 1773 & 854 & 111 & 100 & 1.065 & 1,5 & 2,73 & 1,75 & 88.176 & 20.895 & 12.114 & 33.009 & 3,93 & 231.070 & 317.570 & $32.406,28$ & 42.460 \\
\hline 1774 & 60 & 12 & 117 & 188 & 1,5 & 3,86 & 0,82 & 6.168 & 3.125 & 6.622 & 9.747 & 4,15 & 17.051 & 43.996 & $5.851,89$ & 43.727 \\
\hline 1775 & 1.059 & 97 & 444 & 1.599 & 1,5 & 3,96 & 1,03 & 109.361 & 26.374 & 31.424 & 57.797 & 4,2 & 306.211 & 468.044 & $47.960,03$ & 45.031 \\
\hline 1776 & 849 & 114 & 514 & 1.476 & 1,5 & 3,67 & 1 & 87.684 & 28.698 & 35.534 & 64.232 & 2,7 & 77.834 & 73.455 & $44.970,95$ & 46.374 \\
\hline 1777 & 1.002 & 68 & 731 & 1.802 & 1,5 & 4,37 & 0,9 & 103.509 & 20.366 & 45.141 & 65.507 & 5,7 & 393.342 & 642.273 & $53.507,38$ & 47.756 \\
\hline 1778 & 874 & 169 & 747 & 1.790 & 1,48 & 4,57 & 0,67 & 88.735 & 53.128 & 34.477 & 87.606 & 3,57 & 14.891 & 427.048 & $55.608,94$ & 48.940 \\
\hline 1779 & 841 & 167 & 764 & 1.771 & 1,44 & 4,81 & 0,71 & 83.217 & 55.197 & 37.428 & 92.625 & 3,91 & 226.615 & 478.848 & $55.115,49$ & 50.154 \\
\hline 1780 & 877 & 169 & 781 & 1.827 & 1,45 & 5,04 & 0,76 & 87.584 & 58.562 & 40.982 & 99.544 & 4,26 & 257.140 & 549.393 & $56.746,31$ & 51.397 \\
\hline 1781 & 588 & 150 & 798 & 1.536 & 1,4 & 5,46 & 0,79 & 56.692 & 56.540 & 43.387 & 99.927 & 4,16 & 168.426 & 465.297 & $48.618,36$ & 52.671 \\
\hline 1782 & 1.026 & 178 & 815 & 2.020 & 1,45 & 5,39 & 0,88 & 102.430 & 66.151 & 49.395 & 115.547 & 2,84 & 200.484 & 426.641 & $62.364,44$ & 55.315 \\
\hline 1783 & 766 & 162 & 833 & 1.761 & 1,55 & 5,86 & 0,92 & 81.780 & 65.299 & 52.776 & 118.075 & 2,52 & 32.959 & 324.926 & $55.022,58$ & 56.327 \\
\hline 1784 & 1.464 & 206 & 851 & 2.522 & 1,5 & 5,58 & 1,05 & 151.182 & 79.327 & 61.434 & 140.761 & 2,67 & 269.021 & 519.499 & $77.010,33$ & 57.357 \\
\hline 1785 & 507 & 145 & 870 & 1.522 & 1,65 & 6,55 & 1,02 & 57.555 & 65.438 & 61.102 & 126.540 & 2,97 & 103.450 & 330.896 & $48.563,73$ & 58.406 \\
\hline 1786 & 1.222 & 191 & 889 & 2.302 & 1,65 & 6,22 & 1,18 & 138.825 & 81.811 & 72.108 & 153.919 & 2,97 & 249.528 & 526.186 & $70.672,28$ & 59.474 \\
\hline 1787 & 1.125 & 185 & 9 & 2.218 & 1,4 & 6,14 & 1,22 & 108.401 & 78.152 & 76.241 & 154.393 & 2,97 & 229.637 & 556.702 & $68.271,07$ & 60.562 \\
\hline 1788 & 582 & 150 & 928 & 1.661 & 1,5 & 6,84 & 1,24 & 60.100 & 70.612 & 79.002 & 149.614 & 3,68 & 147.346 & 514.153 & $52.578,37$ & 61.670 \\
\hline 1789 & 846 & 167 & 949 & 1.962 & 1 & 6,21 & 1,31 & 58.237 & 71.316 & 85.795 & 157.111 & 3,44 & 200.351 & 740.857 & $61.024,81$ & 62.798 \\
\hline 1790 & 731 & 160 & 970 & 1.860 & 0,85 & 6,29 & 1,38 & 42.759 & 69.044 & 91.807 & 160.851 & 3,68 & 184.998 & 880.923 & $58.229,63$ & 63.947 \\
\hline 1791 & 668 & 156 & 991 & 1.815 & 0,93 & 6,48 & 1,46 & 42.551 & 69.342 & 99.840 & 169.182 & 4,15 & 191.000 & 950.408 & $57.054,58$ & 65.116 \\
\hline 1792 & 617 & 152 & 1.013 & 1.782 & 1,26 & 6,82 & & 53.658 & 71.490 & 109.900 & 181.390 & 4,3 & 182.769 & 800.621 & $56.260,13$ & 66.307 \\
\hline 1793 & 567 & 149 & 1.035 & 1.750 & 1,6 & 7,09 & 1,69 & 62.401 & 72.747 & 120.646 & 193.393 & 4,45 & 173.500 & 711.207 & $55.505,83$ & 67.520 \\
\hline 1794 & 879 & 169 & & 2.106 & 1,55 & 6,71 & & 93.804 & 78.040 & 135.595 & 213.636 & 5,34 & & 1.058 .852 & $65.400,70$ & 68.755 \\
\hline 1795 & 1.066 & 181 & 1.081 & 2.328 & 2,1 & 7,1 & 2,11 & 154.096 & 88.513 & 156.629 & 245.143 & 5,34 & 391.724 & 1.014 .895 & $71.775,01$ & 70.013 \\
\hline 1796 & 699 & 158 & 1.104 & 1.961 & 2,5 & 5,62 & 1,96 & 120.301 & 60.946 & 149.217 & 210.163 & 4,33 & 208.361 & 572.364 & $61.520,01$ & 72.597 \\
\hline 1797 & 1.079 & 182 & 1.129 & 2.390 & 2,1 & 3,08 & & 156.013 & 38.507 & 60.986 & 99.494 & 4,36 & 323.912 & 530.480 & $73.656,19$ & 74.021 \\
\hline 1798 & 1.371 & 201 & 1.153 & 2.725 & 2,2 & 1,89 & 1,86 & 207.625 & 26.047 & 147.648 & 173.695 & 4,58 & 432.237 & 793.839 & $83.359,97$ & 75.472 \\
\hline 1799 & 1.225 & 191 & 1.179 & 2.595 & 3,2 & 5,73 & 2,71 & 269.797 & 75.365 & 219.948 & 295.313 & 4,8 & 404.695 & 847.665 & $79.641,70$ & 76.952 \\
\hline 1800 & 1.848 & 231 & 1.231 & 3.310 & 2,4 & 8,1 & 1,94 & 305.265 & 128.851 & 164.389 & 293.240 & 5 & 635.969 & 1.246 .885 & $100.496,22$ & 78.461 \\
\hline 1801 & 937 & 173 & 1.231 & 2.340 & 1,9 & 3,06 & 1,42 & 122.515 & 36.421 & 120.122 & 156.542 & 4,6 & 296.614 & 675.612 & $72.508,58$ & 80.000 \\
\hline 1802 & 2.015 & 242 & 1.282 & 3.538 & 1,12 & 5,9 & 1,86 & 154.631 & 98.215 & 164.282 & 262.497 & 4,72 & 654.581 & 1.765 .778 & $107.234,02$ & 80.872 \\
\hline 1803 & 1.790 & 227 & 1.335 & 3.352 & 1,43 & 6,61 & 1,83 & 176.517 & 103.396 & 167.839 & 271.236 & 5,11 & 629.670 & 1.597 .220 & $101.853,77$ & 81.753 \\
\hline 1804 & 1.565 & 213 & 1.390 & 3.168 & 1,75 & 7,77 & 1,84 & 188.587 & 113.848 & 175.944 & 289.791 & 4,84 & 521.577 & 1.323 .057 & $96.576,97$ & 82.643 \\
\hline 1805 & 1.440 & 205 & 1.447 & 3.092 & 3,1 & 9,09 & 1,89 & 307.221 & 128.158 & 187.934 & 316.091 & 5,5 & 545.070 & 1.105 .877 & $94.452,90$ & 83.544 \\
\hline 1806 & 3.081 & 310 & 1.507 & 4.898 & 2,4 & 4,18 & 1,49 & 509.105 & 89.172 & 154.431 & 243.603 & 5,4 & 1.145 .487 & 1.693 .595 & $147.394,50$ & 84.454 \\
\hline 1807. & 2.106 . & 248 . & .1 .569$. & 3.923 & $.2,3$. & $11,84$. & 2,37 & 333.476 . & 201.818 & 255.745. & 457.563 & $.4,6$ & .666 .951 & 1.582 .077 & . 118.789,50. & 85.374. \\
\hline
\end{tabular}


Tabela A-1_ Principais variáveis da economia colonial do Grão-Pará

(conclusão)

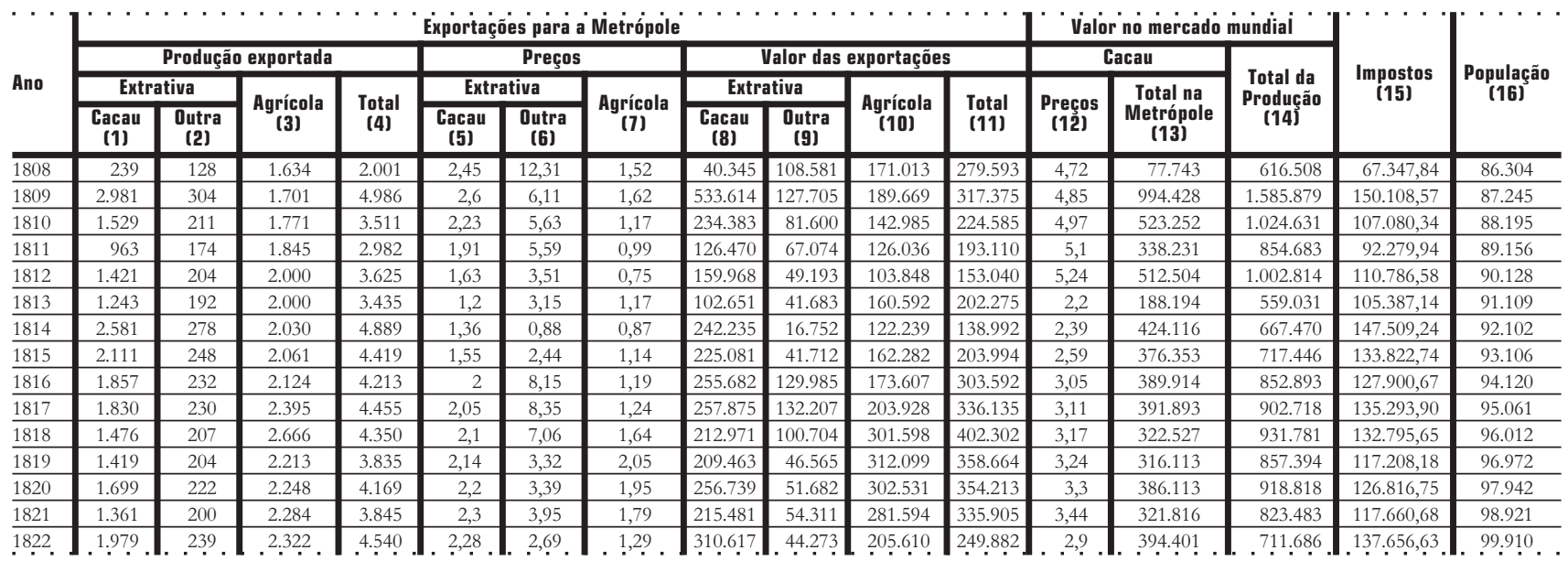

Fontes e notas metodológicas: Produção exportada de cacau em toneladas. De 1730 a 1822 - Alden (1974, Apêndice I, p. 60-62). Valores transformados de libras para toneladas. Para 1763 e 1767, os valores em Alden foram corrigidos com base em Dias (1970, p. 316-360). De 1920 a 1929, baseado nas licenças concedidas para a coleta de cacau conhecidas para $1723(80), 1729(110), 1730(250)$ e 1736 (320), conf. Alden (1974, p. 30-31). Conhecida a produção total do ano de 1730 e 1736 , obtiveram-se as médias de produção por licença, respectivamente de 1,282 t e 1,993 t. Interpolou-se o número de licenças entre 1723 e 1720 pela taxa geométrica de crescimento das concessões entre 1723 e 1729 , multiplicando o resultado para cada ano pela tonelagem média de 1730. Produção exportada de outros produtos extrativos ("drogas do sertão"). De 1756 a 1777, conf. Dias (1970, p. 316-360). De 1720 a 1756 e de 1778 a 1820, aplicaram-se os parâmetros da regressão linear entre "outros produtos extrativos", como variável dependente, e a produção do cacau, observada nas estatísticas de 1756 a 1777 (a constante de 112,773 expressa uma autonomia elevada e o coeficiente angular de 0,064 uma dependência positiva, porém baixa em relação ao cacau; o R2 foi de 0,213). Produção agrícola exportada. De 1756 a 1777, conf. Dias (1970, p. 316-360). Nos anos 1800, 1801, 1812, 1813, 1816 e 1818, conf. Barata (1973, p. 300-330). Fizeram-se interpolações com base nas taxas geométricas verificadas entre os anos conhecidos de cada intervalo. De 1730 a 1755 , utilizaram-se os parâmetros da regressão linear múltipla obtida com os dados de 1756 a 1777 da produção agrícola, como variável dependente, a produção de cacau (coeficiente 0,461$)$ e a produção de outros extrativos (coeficiente -781), com termo constante 19,9 e R2=0,555. Produção exportada total em toneladas: a soma de (1), (2) e (3). Preços no porto de Belém de cacau em toneladas (em $\$ 000$ réis). De 1730 a 1822 - Alden (1974, Apêndice I, p. 60-62). Valores transformados de arrobas para toneladas. Para 1759, há erro em Alden, corrigido; conf. Dias (1970). De 1720 a 1729, indicações em Alden (p. 30). Preços implícitos de outros produtos do extrativismo: (9) $\div(2)$. Preços implícitos de produtos agrícolas: (10) $\div(3)$. Valor da exportação de cacau: (1) x (5), resultados cotejado por Alden (1974) e Dias (1970). Valor das exportações de outros produtos do extrativismo: (11)-(8)-(10). Valor da produção agrícola exportada. De 1756 a 1777, conf. Dias (1970, p. 316-360). Nos anos 1800, 1801, 1812, 1813, 1816 e 1818, conf. Barata (1973, p. 300-330). Fizeram-se interpolações com base em incrementos I = $\mathrm{i}^{*}(\mathrm{v} / \mathrm{a})$, onde I a taxa de incremento para o ano em questão, "i" a taxa geométrica entre os dois pontos conhecidos de (10), " $\mathrm{v}$ " o valor de "V" no ano dividido pela média de "V" no intervalo e "a" a progressão linear da participação de (9) em "V" nos anos conhecidos do intervalo. Isso significa que a agricultura incorpora o total da flutuação da variável agricultura e outros extrativos. Valor das exportações totais. Alden (1974); Barata (1973). O período 1777 a 1796 por interpolação com base em incrementos I = $i^{*}\left(\mathrm{v}^{*} \mathrm{a}\right)$, onde I a taxa de incremento para o ano em questão, "i”" a taxa geométrica entre os dois pontos conhecidos de (11), "v" o valor de (8) no ano dividido pela média de (8) no intervalo e "a" a progressão linear da participação de (8) em (11) nos anos conhecidos do intervalo. Isto é, o valor estimado das exportações totais incorpora a flutuação explicável pela flutuação do cacau. Preços de revenda a partir de Portugal, cotejados pelas cotações em Amsterdam. Alden (1974, Tab. VII, p. 44-55). Valor do cacau vendido na Metrópole e no resto do mundo. Os valores em (1) x (12). Valor da produção da Colônia vendida na Metrópole e no resto do mundo: [(13)/(8)] * (11). Alden (1974) apresenta no Apêndice III as fórmulas de cálculo de impostos sobre cacau e outras "drogas do sertão", como o cravo. Para o cacau, incluindo as gratificações e fazendo as devidas transformações de unidades, encontramos 28.824 réis/arroba; para o cravo, 42.672 réis/arroba. População da Amazônia os valores apresentados em Cardoso (1984, p. 139), com interpolações com base na taxa geométrica entre os pontos 1816 e 1801: 2,98\% a.a.; entre 1802 e 1782: 1,089\% a.a.; entre 1782 e 1765: 1,96\%a.a. De 1765 até 1730, regredi à base de $1 \%$ a.a. 
Tabela A-2_ Valor das exportações por tipo de titulares das cargas e tipo de produto, em Belém, 1755 a 1777 (em \$000)

\begin{tabular}{|c|c|c|c|c|c|c|c|c|c|c|c|c|c|}
\hline \multirow{2}{*}{ Ano } & \multirow[b]{2}{*}{ Agricultura } & \multirow{2}{*}{$\begin{array}{c}\text { Agro } \\
\text { Indústria }\end{array}$} & \multicolumn{2}{|c|}{ Extrativismo } & \multirow[b]{2}{*}{ Pecuária } & \multirow[b]{2}{*}{ Total } & \multirow[b]{2}{*}{ Agricultura } & \multirow[b]{2}{*}{$\begin{array}{c}\text { Agro } \\
\text { Indústria }\end{array}$} & \multicolumn{2}{|c|}{ Extrativismo } & \multirow[b]{2}{*}{ Pecuária } & \multirow[b]{2}{*}{ Total } & \multirow{2}{*}{ Total } \\
\hline & & & Coleta & $\begin{array}{c}\text { Madei- } \\
\text { reiro }\end{array}$ & & & & & Coleta & $\begin{array}{l}\text { Madei- } \\
\text { reiro }\end{array}$ & & & \\
\hline 1756 & 195,00 & & 194,40 & $7.408,62$ & 84,40 & $7.882,42$ & $10.780,20$ & 423,80 & & $61.330,38$ & $8.333,75$ & $80.868,13$ & $88.750,55$ \\
\hline 1757 & 655,20 & 752,50 & 255,96 & $5.883,70$ & & $7.547,36$ & $8.704,80$ & 141,20 & & $50.703,26$ & $4.534,69$ & $64.083,95$ & $71.631,31$ \\
\hline 1758 & 259,20 & 724,10 & 2,00 & $1.925,28$ & 29,00 & $2.939,58$ & $1.783,20$ & $1.015,30$ & & $7.184,47$ & $2.433,25$ & $12.416,21$ & $15.355,79$ \\
\hline 1759 & $9.050,00$ & 359,70 & 67,02 & $41.561,60$ & $4.254,82$ & $55.293,14$ & $1.706,00$ & 126,50 & 21,00 & $17.956,80$ & 239,75 & $20.050,05$ & $75.343,19$ \\
\hline 1760 & $19.130,40$ & & 254,83 & $90.261,04$ & $7.286,68$ & $116.932,95$ & $1.352,80$ & 10,40 & & $20.274,96$ & $1.622,80$ & $23.260,96$ & $140.193,91$ \\
\hline 1761 & $13.997,60$ & & 121,28 & $76.937,00$ & $5.283,50$ & $96.339,37$ & 586,80 & 124,80 & & $22.807,70$ & $10.847,37$ & $34.366,67$ & $130.706,04$ \\
\hline 1762 & $8.971,20$ & & 292,20 & $117.278,00$ & $5.279,33$ & $131.820,73$ & 225,60 & & & $15.753,70$ & 56,50 & $16.035,80$ & $147.856,53$ \\
\hline 1763 & $6.333,60$ & & $18.666,00$ & $61.501,10$ & $1.768,03$ & $88.268,73$ & & & & $6.632,50$ & $1.206,46$ & $7.838,96$ & $96.107,70$ \\
\hline 1764 & $10.137,60$ & & & $69.046,50$ & $1.170,10$ & $80.354,20$ & 276,00 & & & $1.969,50$ & $9.119,70$ & $11.365,20$ & $91.719,40$ \\
\hline 1766 & $11.462,40$ & & 844,36 & $64.161,00$ & 73,30 & $76.541,06$ & 784,80 & & 64,00 & $5.362,00$ & $6.081,38$ & $12.292,18$ & $88.833,24$ \\
\hline 1767 & $14.399,51$ & & 625,28 & $64.211,30$ & & $79.236,09$ & $1.319,07$ & & 65,62 & $2.898,90$ & $5.256,39$ & $9.539,98$ & $88.776,07$ \\
\hline 1768 & $9.517,60$ & & 854,29 & $80.942,50$ & & $91.314,39$ & 259,20 & 176,00 & & 192,00 & & 627,20 & $91.941,59$ \\
\hline 1769 & 480,00 & & 309,25 & $2.074,10$ & & $2.863,35$ & 21,60 & 240,00 & & 408,13 & 637,20 & $1.306,93$ & $4.170,28$ \\
\hline 1770 & $4.759,20$ & & $1.970,01$ & $94.171,80$ & 109,44 & $101.010,45$ & $2.852,00$ & & 7,00 & $6.856,40$ & $3.929,20$ & $13.644,60$ & $114.655,05$ \\
\hline 1771 & $11.845,60$ & 867,00 & $5.780,24$ & $66.309,38$ & & $84.802,22$ & $6.432,30$ & 140,00 & 856,80 & $12.532,80$ & $3.156,60$ & $23.118,50$ & $107.920,72$ \\
\hline 1772 & $7.694,40$ & $3.842,00$ & 268,40 & $94.651,35$ & & $106.456,15$ & $4.019,20$ & 166,00 & 4,00 & $6.420,00$ & $3.540,40$ & $14.149,60$ & $120.605,75$ \\
\hline 1773 & $3.741,60$ & 864,00 & 295,74 & $99.341,40$ & 42,00 & $104.284,74$ & $6.934,35$ & 91,00 & 139,17 & $9.294,40$ & 441,00 & $16.899,92$ & $121.184,66$ \\
\hline 1774 & $1.934,25$ & 55,00 & & $9.101,40$ & & $11.090,65$ & $1.865,10$ & & & 191,80 & $2.767,90$ & $4.824,80$ & $15.915,45$ \\
\hline 1775 & $15.560,40$ & 479,00 & & $135.142,68$ & & $151.182,08$ & $12.396,70$ & & & 591,33 & $2.987,50$ & $15.975,53$ & $167.157,61$ \\
\hline 1776 & $17.366,70$ & $3.119,59$ & $1.152,46$ & $108.846,34$ & & $130.485,09$ & $9.996,10$ & & $1.454,80$ & $4.928,40$ & $5.051,80$ & $21.431,10$ & $151.916,19$ \\
\hline 1777 & $24.361,05$ & $2.629,75$ & & $114.060,80$ & $1.192,32$ & 142.243,92 & $12.076,60$ & 18,00 & & $9.453,40$ & $4.863,44$ & $26.772,13$ & $169.016,05$ \\
\hline
\end{tabular}

Fonte: Nunes Dias (1970, p. 316-360). Tabulações especiais do autor.

Nota metodológica: Tomaram-se as informações anuais fornecidas por Dias, produto a produto, por tipo de rubrica, se "Companhia" ou se "Colonos", e formou-se um banco de dados próprio, tabulado com os recursos do SPSS. Os valores agregados apresentam diferenças com Nunes Dias em várias situações por equívocos de soma. Tivemos o cuidado de, nessas situações, cotejar com outras fontes, principalmente Carreira (1988). 
Tabela A-3_ Valor das exportações estimadas por estruturas produtivas e tipo de produto, em Belém, 1755 a 1777 (em \$000)

\begin{tabular}{|c|c|c|c|c|c|c|c|c|c|c|c|c|c|c|c|c|c|c|c|}
\hline \multirow{2}{*}{ Ano } & \multirow{2}{*}{$\begin{array}{c}\text { Agri- } \\
\text { cultura }\end{array}$} & \multirow{2}{*}{$\begin{array}{c}\text { Agro } \\
\text { Indúst. }\end{array}$} & \multicolumn{2}{|c|}{ Extrativismo } & \multirow{2}{*}{$\begin{array}{l}\text { Pecuá- } \\
\text { ria }\end{array}$} & \multirow[b]{2}{*}{ Total } & \multirow{2}{*}{$\begin{array}{c}\text { Agri- } \\
\text { cultura }\end{array}$} & \multirow{2}{*}{$\begin{array}{c}\text { Agro } \\
\text { Indúst. } \\
\text { Coleta }\end{array}$} & \multicolumn{2}{|c|}{ Extrativismo } & \multirow{2}{*}{$\begin{array}{c}\text { Pecuá- } \\
\text { ria }\end{array}$} & \multirow{2}{*}{ Total } & \multirow{2}{*}{$\begin{array}{c}\text { Agro } \\
\text { Indúst. } \\
\text { Coleta }\end{array}$} & \multirow{2}{*}{$\begin{array}{c}\text { Agro } \\
\text { Indúst. }\end{array}$} & \multicolumn{2}{|c|}{ Extrativismo } & \multirow{2}{*}{$\begin{array}{c}\text { Pecuá- } \\
\text { ria }\end{array}$} & \multirow[b]{2}{*}{ Total } & \multirow{2}{*}{ Total } \\
\hline & & & Coleta & $\begin{array}{c}\text { Madei- } \\
\text { reiro }\end{array}$ & & & & & Coleta & $\begin{array}{c}\text { Madei- } \\
\text { reiro }\end{array}$ & & & & & Coleta & $\begin{array}{c}\text { Madei- } \\
\text { reiro }\end{array}$ & & & \\
\hline 756 & 195,0 & & 194,4 & $7.408,6$ & 84,4 & $7.882,4$ & $2.790,7$ & 5,5 & & $16.782,4$ & $1.329,1$ & $20.907,6$ & $7.989,5$ & 418,3 & - & $44.548,0$ & $7.004,6$ & $59.960,5$ & $88.750,6$ \\
\hline 1757 & 655,2 & 752,5 & 256,0 & $5.883,7$ & & $7.547,4$ & $2.380,0$ & 11,5 & & $13.815,5$ & 716,0 & $16.923,0$ & $6.324,8$ & 129,7 & - & $36.887,8$ & $3.818,7$ & $47.161,0$ & $71.631,3$ \\
\hline 1758 & 259,2 & 724,1 & 2,0 & $1.925,3$ & 29,0 & $2.939,6$ & 519,3 & 22,4 & & $2.224,1$ & 388,8 & $3.154,6$ & $1.263,9$ & 992,9 & - & $4.960,4$ & $2.044,5$ & $9.261,6$ & $15.355,8$ \\
\hline 1759 & $3.298,0$ & 336,0 & 84,6 & $17.423,7$ & $1.314,8$ & $22.457,1$ & $2.735,0$ & 6,3 & & $14.531,2$ & 709,6 & $17.982,0$ & $4.723,0$ & 143,9 & 3,4 & $27.563,5$ & $2.470,1$ & $34.904,0$ & $75.343,2$ \\
\hline 1760 & $6.280,5$ & & 244,9 & $32.358,9$ & $2.606,3$ & $41.490,7$ & $1.352,8$ & 10,4 & & $20.275,0$ & $1.622,8$ & $23.261,0$ & $12.849,9$ & - & 9,9 & $57.902,1$ & $4.680,3$ & $75.442,2$ & $140.193,9$ \\
\hline 1761 & $4.471,9$ & & 116,6 & $29.199,8$ & $4.718,9$ & $38.507,1$ & 586,8 & 124,8 & & $22.807,7$ & $10.847,4$ & $34.366,7$ & $9.525,7$ & - & 4,7 & $47.737,2$ & 564,6 & $57.832,3$ & $130.706,0$ \\
\hline 1762 & $2.819,9$ & & 280,8 & $38.944,4$ & $1.560,9$ & $43.606,1$ & 225,6 & - & & $15.753,7$ & 56,5 & $16.035,8$ & $6.151,3$ & & 11,4 & $78.333,6$ & $3.718,4$ & $88.214,6$ & $147.856,5$ \\
\hline 1763 & $1.942,0$ & & $17.940,6$ & $19.945,8$ & 870,1 & $40.698,6$ & 250,8 & - & & $6.632,5$ & $1.206,5$ & $8.089,8$ & $4.140,8$ & & 725,4 & $41.555,3$ & 897,9 & $47.319,4$ & $96.107,7$ \\
\hline 1764 & $3.193,0$ & & & $20.789,6$ & $1.170,1$ & $25.152,7$ & 276,0 & - & & $1.969,5$ & $9.119,7$ & $11.365,2$ & $6.944,6$ & & - & $48.256,9$ & 0,0 & $55.201,5$ & $91.719,4$ \\
\hline 1765 & $4.753,1$ & & $2.464,9$ & $19.910,6$ & 265,9 & $27.394,5$ & 702,0 & - & & $4.632,0$ & $4.324,3$ & $9.658,3$ & $10.046,5$ & & 99,7 & $43.470,7$ & 0,0 & $53.616,9$ & $90.669,7$ \\
\hline 1766 & $3.755,2$ & & 844,4 & $20.352,5$ & 73,3 & $25.025,4$ & 784,8 & - & 64,0 & $5.362,0$ & $6.081,4$ & $12.292,2$ & $7.707,2$ & & 0,0 & $43.808,5$ & $(0,0)$ & $51.515,6$ & $88.833,2$ \\
\hline 1768 & $2.997,8$ & & 821,1 & $23.751,8$ & - & $27.570,6$ & 259,2 & 176,0 & - & 192,0 & $2.946,8$ & $3.574,0$ & $6.519,8$ & & 33,2 & $57.190,7$ & $(2.946,8)$ & $60.797,0$ & $91.941,6$ \\
\hline 1769 & 153,8 & & 297,2 & 726,7 & & $1.177,7$ & 21,6 & 240,0 & - & 408,1 & 637,2 & $1.306,9$ & 326,2 & & 12,0 & $1.347,4$ & & $1.685,7$ & $4.170,3$ \\
\hline 1770 & $2.333,7$ & - & $1.900,2$ & $29.575,6$ & 109,4 & $33.918,9$ & $2.852,0$ & - & 7,0 & $6.856,4$ & $3.929,2$ & $13.644,6$ & $2.425,5$ & & 69,8 & $64.596,2$ & 0,0 & $67.091,5$ & $114.655,1$ \\
\hline 1771 & $5.604,4$ & 695,9 & $5.780,2$ & $23.080,7$ & & $35.161,2$ & $6.432,3$ & 140,0 & 856,8 & $12.532,8$ & $3.156,6$ & $23.118,5$ & $6.241,2$ & 171,1 & 0,0 & $43.228,7$ & 0,0 & $49.641,1$ & $107.920,7$ \\
\hline 1772 & $3.591,6$ & $2.769,7$ & 261,8 & $29.588,2$ & & $36.211,3$ & $4.019,2$ & 166,0 & 4,0 & $6.420,0$ & $3.540,4$ & $14.149,6$ & $4.102,8$ & $1.072,3$ & 6,6 & $65.063,2$ & & $70.244,9$ & $120.605,8$ \\
\hline 1773 & $3.273,5$ & 659,9 & 295,7 & $31.802,6$ & 42,0 & $36.073,8$ & $6.934,4$ & 91,0 & 139,2 & $9.294,4$ & 441,0 & $16.899,9$ & 468,1 & 204,1 & $(0,0)$ & $67.538,8$ & $(0,0)$ & $68.211,0$ & $121.184,7$ \\
\hline 1774 & $1.165,0$ & 38,0 & & $2.720,5$ & & $3.923,5$ & $1.865,1$ & - & - & 191,8 & $2.767,9$ & $4.824,8$ & 769,3 & 17,0 & - & $6.380,9$ & & $7.167,1$ & $15.915,5$ \\
\hline 1775 & $8.572,2$ & 331,0 & & $39.735,5$ & & $48.638,7$ & $12.396,7$ & - & - & 591,3 & $2.987,5$ & $15.975,5$ & $6.988,2$ & 148,0 & - & $95.407,2$ & - & $102.543,4$ & $167.157,6$ \\
\hline 1776 & $8.390,0$ & $2.155,7$ & $1.152,5$ & $33.307,0$ & & $45.005,2$ & $9.996,1$ & - & $1.454,8$ & $4.928,4$ & $5.051,8$ & $21.431,1$ & $8.976,7$ & 963,8 & 0,0 & $75.539,3$ & - & $85.479,9$ & $151.916,2$ \\
\hline 777. & $11.172,5$ & 1.829,7 & & 36.158,2 & $1.192,3$ & $50.352,7$ & 12.076,6. & 18,0 & 360,7 & 9.453,4. & $4.863,4$ & $26.772,1$ & $13.188,6$ & 800,1 & - & $77.902,6$ & 0,0 & $91.891,2$ & $169.016,1$ \\
\hline
\end{tabular}

Fonte: Nunes Dias (1970, p. 316-360).

Notas metodológicas: 1) A produção embarcada até 1759 sob a titularidade da "Companhia” provinha apenas dos Diretórios: sua proporção no total exportado nessa fase fornece a base para o cálculo da "verdadeira produção" dessas estruturas; 2) A estrutura produtiva dos colonos de origem europeia, dependentes do trabalho escravo negro, na agricultura, e da repartição do trabalho dos índios aldeados, no extrativismo terá seu peso real expresso somente nos quinquênios pós-1760, quando só puderam transacionar a própria e efetiva produção: as proporções aí verificadas fornecem as bases para o cálculo de sua "verdadeira produção"; 3 ) A produção dos produtores invisíveis (camponeses) é igual ao total exportado em cada ano, menos a "verdadeira produção" dos Diretórios, menos ainda a "verdadeira produção" dos colonos. A produção dos Diretórios até 1760 é igual ao que foi exportado sob a rubrica "Companhia". A partir de 1760, é igual à percentagem média da rubrica "Companhia" no total da produção exportada até 1760 - sublinhe-se, a participação histórica conhecida dos Diretórios no total da exportação - vezes o total da produção exportada dos anos posteriores a 1760. A verdadeira produção dos colonos será, após 1760, o que foi exportado sob a rubrica "Colonos”; antes de 1760, a participação relativa média da rubrica "Colonos" no total da produção exportada, após 1760 , vezes o total da produção exportada dos anos anteriores a 1760. 